\title{
DiD the COMmercial PAPER FUnding FACILITY PreVent a Great Depression Style Money MARKET MELTDOWN?
}

\author{
JOHN V. DUCA
}

RESEARCH DEPARTMENT

WORKING PAPER 1101

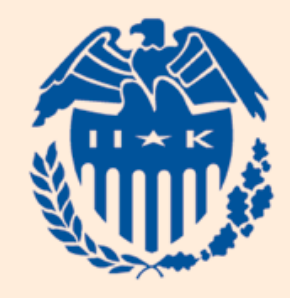

Federal Reserve Bank of Dallas 


\title{
Did the Commercial Paper Funding Facility Prevent a Great Depression Style Money Market Meltdown?
}

\author{
John V. Duca ${ }^{*}$ \\ Vice President and Senior Policy Advisor \\ Research Department, Federal Reserve Bank of Dallas \\ P.O. Box 655906, Dallas, TX 75265 \\ (214) 922-5154, john.v.duca@dal.frb.org \\ and Adjunct Professor, Southern Methodist University, Dallas, TX
}

May 2009 (revised, February 2011)

This paper analyzes how risk premia — and other factors affecting the comparative advantages of security-funded versus deposit-funded short-run debt-altered the relative use of debt funded by securities markets since the early-1960s and the relative use of commercial paper during the recent financial crisis. Results indicate that lower risk premia, higher information costs, and reserve requirement costs induce less relative use of commercial paper and short-run debt funded by securities markets. This paper also finds that Federal Reserve interventions in the money market helped prevent the commercial paper market from melting down to the extent seen during the early 1930 s.

JEL Codes: E44, E50, N12

Key Words: Great Depression, Commercial Paper, Financial Frictions, Credit Rationing

*I thank Danielle DiMartino, Steen Ejerskov, and Gustavo Suarez for suggestions, David Luttrell for research assistance, and seminar participants at the European Central Bank, the 2009 Bank of Canada - Simon Fraser University Conference on Financial Market Stability, and the 2009 Federal Reserve's "Day-Ahead (of the ASSA meetings)" conference. The views expressed are those of the author's and are not necessarily those of the Federal Reserve Bank of Dallas or the Federal Reserve System. 
This paper assesses whether Federal Reserve and Treasury efforts to improve liquidity conditions in money markets helped stabilize the use of commercial paper during the recent financial crisis. It does this primarily by analyzing the relative use of commercial paper versus bank loans during the recent financial crisis along with longer time series data establishing a link between liquidity spreads and the relative use of debt funded by securities markets.

Theoretical models of financial frictions imply that credit will shift from risky to safer borrowers if economic factors increase default risk or increase the cost of loanable funds via increasing liquidity risk premiums (e.g., Bernanke and Blinder, 1988; Bernanke and Gertler, 1989; Bernanke, Gertler, and Gilchrist, 1996; Jaffee and Russell, 1976; Keeton, 1979; Lang and Nakamura, 1995; and Stiglitz and Weiss, 1981). And a more recent literature has emphasized the vulnerability of financial firms and the financial system to liquidity risk (Adrian and Shin (2009, forthcoming). Consistent with these theories, the experience of the Great Depression indicates that security-funded sources of external finance, such as commercial paper, are vulnerable to the jumps in risk premiums typical of financial crises (Duca, 2009). Indeed, when spreads between corporate and treasury bond yields jumped, real commercial paper outstanding fell 85 percent between July 1930 and May 1933, and the relative and absolute use of bankers acceptances (BA's) rose (Figure 1). BAs are also money market instruments but unlike the unbacked commercial paper of that era, BA's were collateralized and made more liquid by the Fed's conduct of open market operations in BA's. ${ }^{1}$

Recent experience suggests that surges in risk premiums can be countered by central bank asset purchases which cushion the supply of security-funded credit to top-rated borrowers

\footnotetext{
${ }^{1}$ BAs are time drafts drawn on banks to finance the shipment or storage of goods. Banks guarantee payment to BA owners, making BAs tradeable as investors know more about banks than goods buyers. The latter receive credit to pay sellers from banks which fund credits by selling BAs. Good collateralize BAs for banks, but asset-backed paper is backed by paper assets whose values fell after 2006. Using ratios of BAs and paper abstracts from other factors.
} 
(see Goodhart, 1987 for a discussion on the need for a broad lender of last resort). For example, real commercial paper fell 74 percent during the 25 months between July 1930 and August 1932, but by a less dramatic 44 percent between July 2007 and August 2009. In contrast to the 1930s, the Fed has recently sought to limit surges in risk premia on high-grade commercial paper and residential mortgage-backed securities through several programs. Some of the smaller decline in paper also reflects the stronger macroeconomic policy response in the recent crisis.

Figure 1: Domestic Bankers Acceptances Rose Relative to Commercial Paper Shortly After Corporate Bond Risk Spreads Rose During the Depression

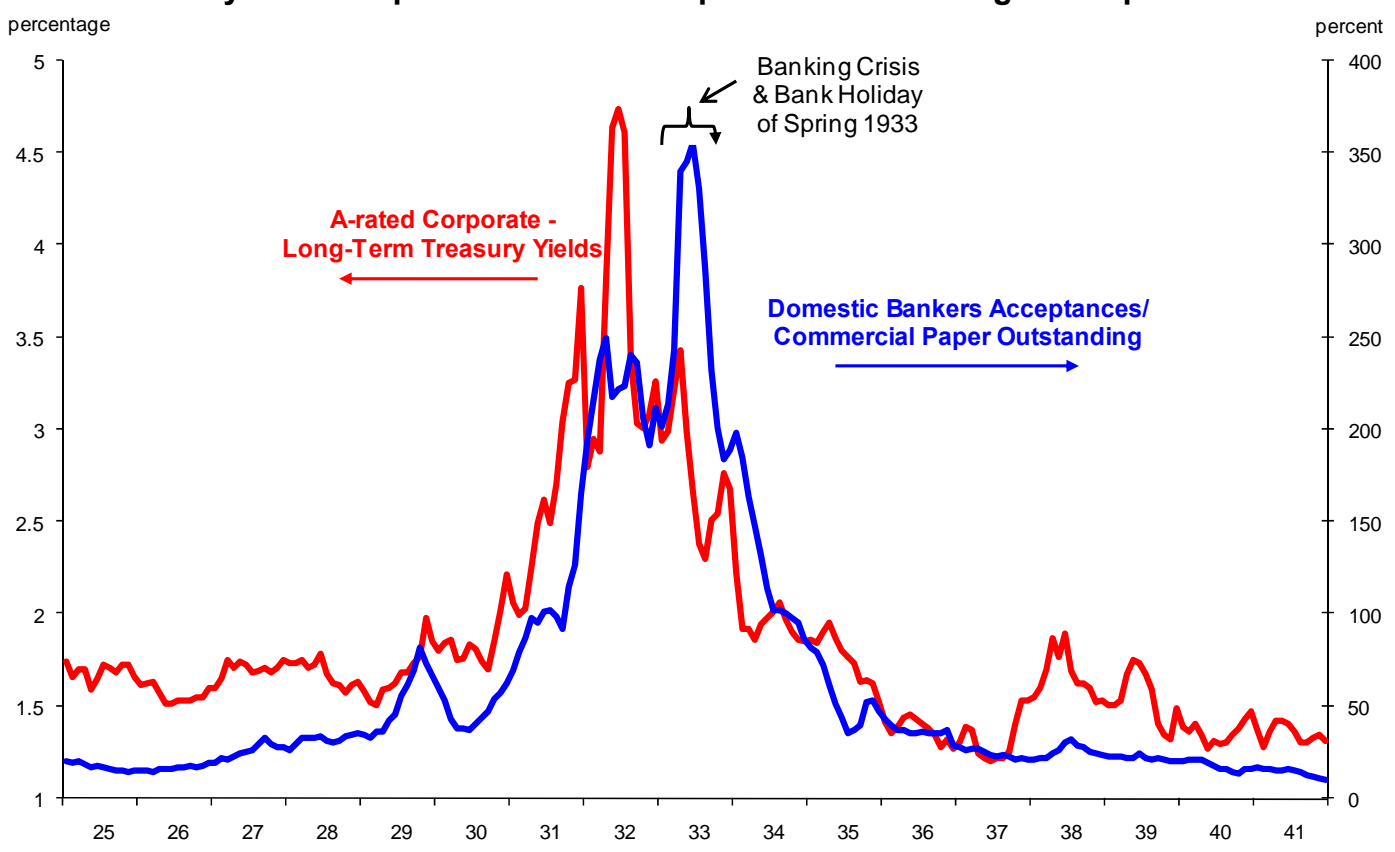

To distinguish among these factors we assess the Fed's recent unusual money market interventions by modeling the relative use of bank loans versus commercial paper. This approach follows others who analyze the composition of business credit, dating back to Jaffee and Modigliani (1969 who analyze the composition of bank business loans, and extending to recent papers, such as Kashyap, Wilcox, and Stein (1993), who analyze the relative use of commercial paper and bank loans. These studies, especially the flight-to-quality model of Lang and Nakamura (1995) and the financial accelerator approach of Bernanke and Gertler (1989) and 
Bernanke, Gertler, and Gilchrist (1996), imply that the composition of credit shifts away from security funded debt toward deposit-funded debt during periods of high corporate risk premiums.

We follow Kashyap, Wilcox, and Stein (1997) by modeling (1) total commercial paper outstanding as a share of itself plus business loans or (2) the relative use of security-funded credit to itself plus bank loans. The latter is partly based on Oliner and Rudebusch's (1995) emphasis on a broad-based rather than a narrow (bank) -based view of the credit channel of monetary policy, and uses Flow of Funds data since 1954 and covers a broad range of credit funded with commercial paper and other market debt. The relative use of credit funded by commercial paper (e.g., commercial paper and nonbank loans funded by securities by finance companies and ABS lenders) versus bank intermediated credit reflects the advantages of avoiding bank regulations (e.g., reserve and capital requirements) relative to the advantages of banks having any informational/transactions cost advantages in lending and funding sources that are less exposed to swings in market liquidity and default risk premia.

In this way, the relative use of security funded credit reflects the combination of insights from (1) an older literature emphasizing how reserve and other regulatory requirements encourage the use of alternatives to bank loans (e.g., Kanatas and Greenbaum, 1982), (2) the theoretical and empirical literature that models the securitization of bank loans (e.g., Pennacchi, 1988), and (3) a newer literature examining the role of swings in liquidity premia and leverage in generating the recent financial crisis (e.g., Adrian and Shin, 2009a, 2009b, forthcoming). With regard to the latter, the ability of lenders to fund loans by issuing debt—whether through securitization either by banks or by ABS entities - depends critically on how much collateral investors demand — or equivalently how much leverage markets will allow such lenders to take. In their model of lenders funding loans without insured deposits, Schleiffer and Vishny (2010) 
theoretically show that such lending can dry up if investors demand higher risk premia, a point which Adrian and Shin (2009a,b) empirically demonstrate and which Adrian and Shin (forthcoming) analyze in a more market-oriented context.

This paper also analyzes another measure of the composition of credit, (CPBLMIX), which is consistently defined since 2001 as a percent of commercial paper and commercial and industrial (C\&I) loans at commercial banks. It differs from the mix variable of Kashyap, et al (1997) in including all commercial paper, not just nonfinancial corporate paper. The reason is the increased borrowing during the early 2000s by nonfinancial firms from financial entities who funded credit by issuing asset-backed paper. The rising market share of paper-funded lending reflected declines in the relative use of paper directly by nonfinancial firms and of bank loans. The relative use of paper versus loans is affected by the relative cost of firms directly or indirectly borrowing from securities markets (avoiding bank regulatory costs) versus borrowing from banks relying on insured deposits. Thus, when the collateral value of assets backing assetbacked paper became less valuable when financial risk premia rose in the crisis, the relative funding costs advantages and use of commercial paper fell (Gorton and Metrick, 2009).

Indeed, between July 2007 (before the hedge fund event of August 2007) and the failure of Lehman Brothers, the relative use of commercial paper fell 10 percentage points when the spread between the Baa corporate and 10-year Treasury yield rose by 1.5 percentage points (Figure 2). After the Fed announced its commercial paper purchase program in October 2008, spreads rose by a larger 2-3 percentage points while the paper-mix variable fell by a smaller 6-8 percentage points by July 2009. Results indicate that this is not a coincidence, implying that new Federal Reserve programs helped prevent commercial paper from imploding by as much as it did in the 1930s. Section 2 reviews factors affecting the relative use of commercial paper (and 
security-funded debt) versus bank loans and variables tracking those factors. Section 3 presents the empirical results using quarterly data back to the early 1960s, while Section 4 analyzes higher frequency monthly data that that are consistently available since 2001. Results are interpreted in Section 5, which draws parallels with the experience of the 1930s.

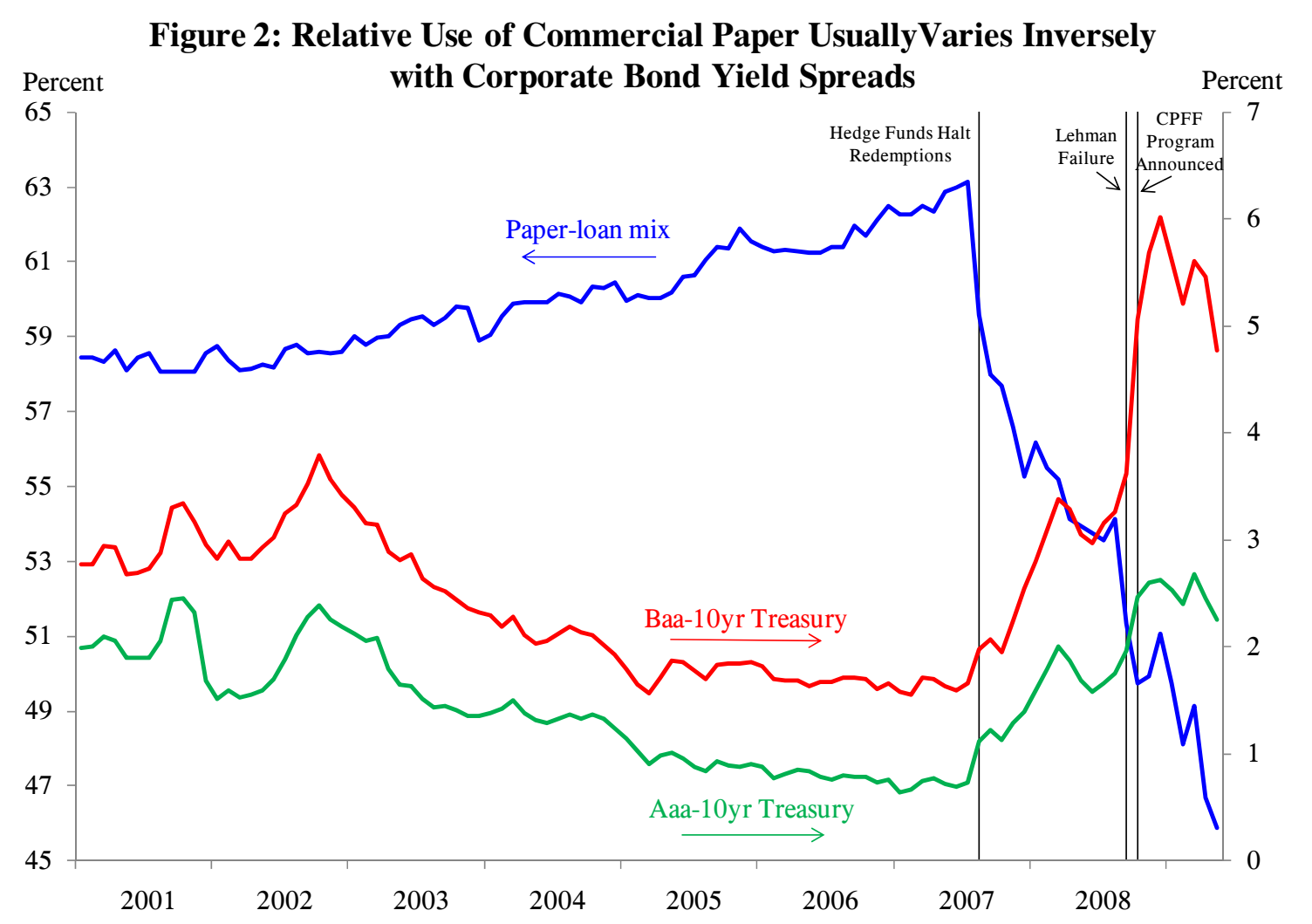

\section{Specifications and Data}

\section{A. Modeling the Relative Use of Commercial Paper-Funded versus Deposit-Funded Loans}

The long-run relative use of commercial paper-funded credit $(C P F C)$ can be modeled as a function of nonstationary ( $X$ vector) and stationary ( $Y$ vector) regulatory and risk variables reflecting the factors mentioned above. Short-run changes in $C P F C$ can be modeled as a function of an error-correction term ( $E C \equiv$ actual minus equilibrium log-levels of $C P F C$ ), shortrun variables, and first-differences of any nonstationary $X$ components: 


$$
\begin{aligned}
& \log (C P F C)=\lambda_{0}+\lambda_{1} \log (X)+\lambda_{2}(Y) \\
& \Delta \log (C P F C)_{\mathrm{t}}=\alpha_{0}+\alpha_{1} \log (E C)_{\mathrm{t}-1}+\beta_{\mathrm{i}} \Delta \log (C P F C)_{\mathrm{t}-\mathrm{i}}+\theta_{\mathrm{i}} \Delta \log (X)_{\mathrm{t}-\mathrm{i}}+\delta Y_{\mathrm{t}} \\
& E C \equiv \log (C P F C)-\left[\lambda_{0}+\lambda_{1} \log (X)\right]
\end{aligned}
$$

This approach can be implemented with enough time series data. Unfortunately, the only consistent and long-running time series source of data to track $C P F C$ into the recent crisis period is the quarterly Flow of Funds data base. Higher frequency monthly data on commercial paper that span direct and asset-back commercial paper suffer from sample breaks, and are consistently available only since 2001. This makes it difficult to identify long-run relationships and short samples are plagued by short-run trends. Monthly data on the use of commercial paper relative to bank loans (CPBLMIX) are modeled over 2001:02-2009:09 using a simple first difference model:

$$
\Delta \log (C P B L M I X)_{\mathrm{t}}=\alpha_{0}+\beta_{\mathrm{i}} \Delta \log (C P B L M I X)_{\mathrm{t}-\mathrm{i}}+\theta_{\mathrm{i}} \Delta \log (X)_{\mathrm{t}-\mathrm{i}}+\delta Y_{\mathrm{t}}
$$

\section{B. Data and Variables}

Variables track the following types of factors: the use of security-funded credit, reserve requirements, information/transactions costs, capital requirements, risk premia, credit market interventions, disintermediation and deregulation, and monthly event risk and inventory demand.

\section{Relative Use of Commercial Paper-Funded Credit}

Two measures of the relative use of commercial paper-funded credit are analyzed. The first, $C P F C$, is a ratio of quarterly Flow of Funds data on nonfinancial corporate debt since 1960:q1 (Figure 2). CPFC equals the sum of directly issued commercial paper plus finance company loans plus other loans financed by asset-backed commercial paper (securitized C\&I loans help by ABS issuers and loans by ABS issuers to nonfinancial corporate business) divided by the sum of directly issued commercial paper, bank loans and all other loans (the last category includes finance company loans and asset-backed securities (ABS)-funded loans). 
The regression models start in 1961:q1, owing to some prior sample breaks stemming from shifts in underlying source data that cause discrete shifts in CPFC in the late 1950s. Several changes were made to Flow of Funds data collected after 1973:q1 which likely led to quarterly models of first differences of CPFC having a large outlier in that quarter. To control for this a 0-1 dummy (Break1973q1) was included in all short-run quarterly models.

The other measure of security-funded credit, CPBLMIX, is the ratio of domestic issued commercial paper to itself plus bank loans (Figure 2). The numerator includes commercial paper issued by financial corporations to track asset-backed commercial paper that largely funded loans to nonfinancial corporations. A drawback of CPBLMIX is that its commercial paper component funds consumer credit. To address this, an alternative, corresponding set of models was estimated in which the bank loan component of an alternative mix variable includes consumer loans held on bank balance sheets.

\section{Tracking the Burden of Reserve Requirements}

The reserve requirement tax can be proxied by nominal interest rates up until when the Fed started paying interest on reserves in 2008:q4. However, the 3-month T-bill rate (3monTR) was I(2) rather than I(1) (an $X$ variable) over the post-Treasury Accord era, but has the drawback of ignoring substantial changes in reserve requirements. A more precise measure calculates the reserve requirement tax $(R R T A X)$ as the product of the 3-month T-bill rate and the highest reserve requirement (Figure 3) on banks in central reserve city banks (mainly large banks), with an adjustment for the advent of sweep accounts (Anderson and Rasche, 2001; Dutkowsky and Cynamon, 2003) that shift balances overnight out of reservable checking accounts into MMDAs to help avoid the implicit reserve requirement tax. The adjustment equals one minus the ratio of swept balances to the sum of swept balances (Federal Reserve Bank of St. Louis, 2010), 
reservable demand deposits, and reservable other checkable deposits. The adjustment is internally consistent with the calculation of the reserve requirement tax in that the estimated reduction in required reserves balances of about 10 percent of sweep balances (St. Louis Federal Reserve Bank, 2010) roughly equals the maximum 10 percent marginal reserve requirement for large banks, the ratio used to gauge the reserve requirement tax. Near zero short-term Treasury bill rates and the payment of roughly similar interest on reserves since 2008:q4, the reserve requirement tax equals 0.01 percent over 2008:q4 to 2009:q4.

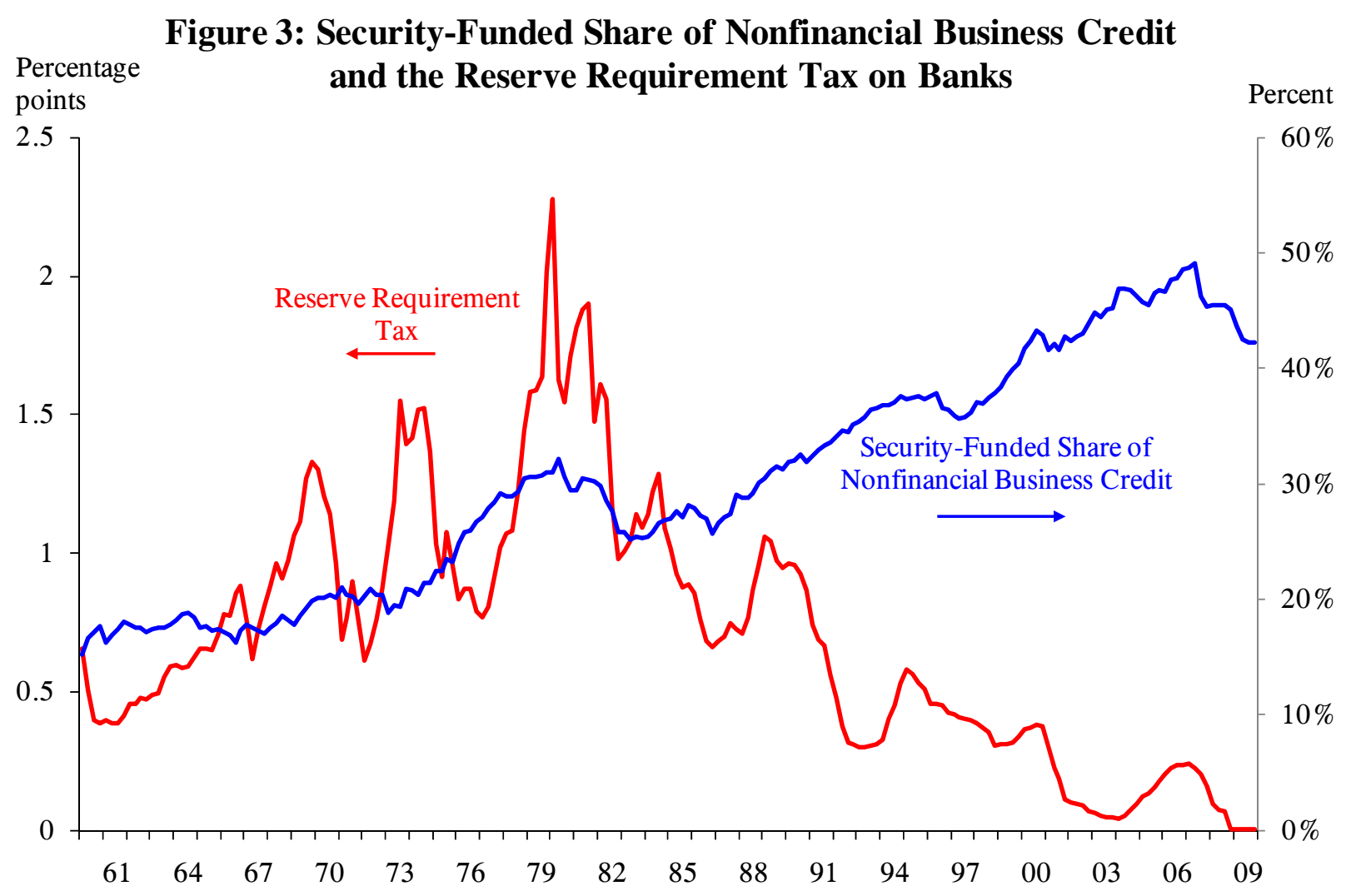

\section{Tracking Long-Run Information and Transactions Costs}

The most generally accepted view of factors affecting the relative importance of banks emphasizes not only the burden of regulations like reserve requirements, but also how the informational and transactions cost advantages of banks over nonbanks have eroded over time 
owing to improvements in technology (e.g., Edwards and Mishkin, 1995, and Mishkin, 2009).

Studies of the rising importance of mutual funds emphasize the role played by declining transactions costs at nonbanks, which stem from improvements in overall financial sector productivity (Duca, 2000 and 2005). To parsimoniously model the influence of general declines in information costs that likely capture declines in transactions costs, long-run models include a measure of information technology prices. Annual data on the quality-adjusted information technology price index of Jorgenson and Stiroh (2007) were interpolated into quarterly readings using a cubic spline, and were then deflated by the overall GDP chain price deflator. Annual price readings for 2007-2009 extend the Jorgenson-Stiroh annual data beyond 2006 by assuming that nominal prices continued falling at the 4.69 percent pace observed over $2003-06$. The resulting series, RPIT (Figure 4), should be negatively related to the security-funded share of business credit because declines in this real, relative price should generally reflect the factors that reduce the informational and transactions cost advantages of bank over nonbank intermediaries.

Figure 4: Real Information Technology Costs and Aaa-Treasury Spread

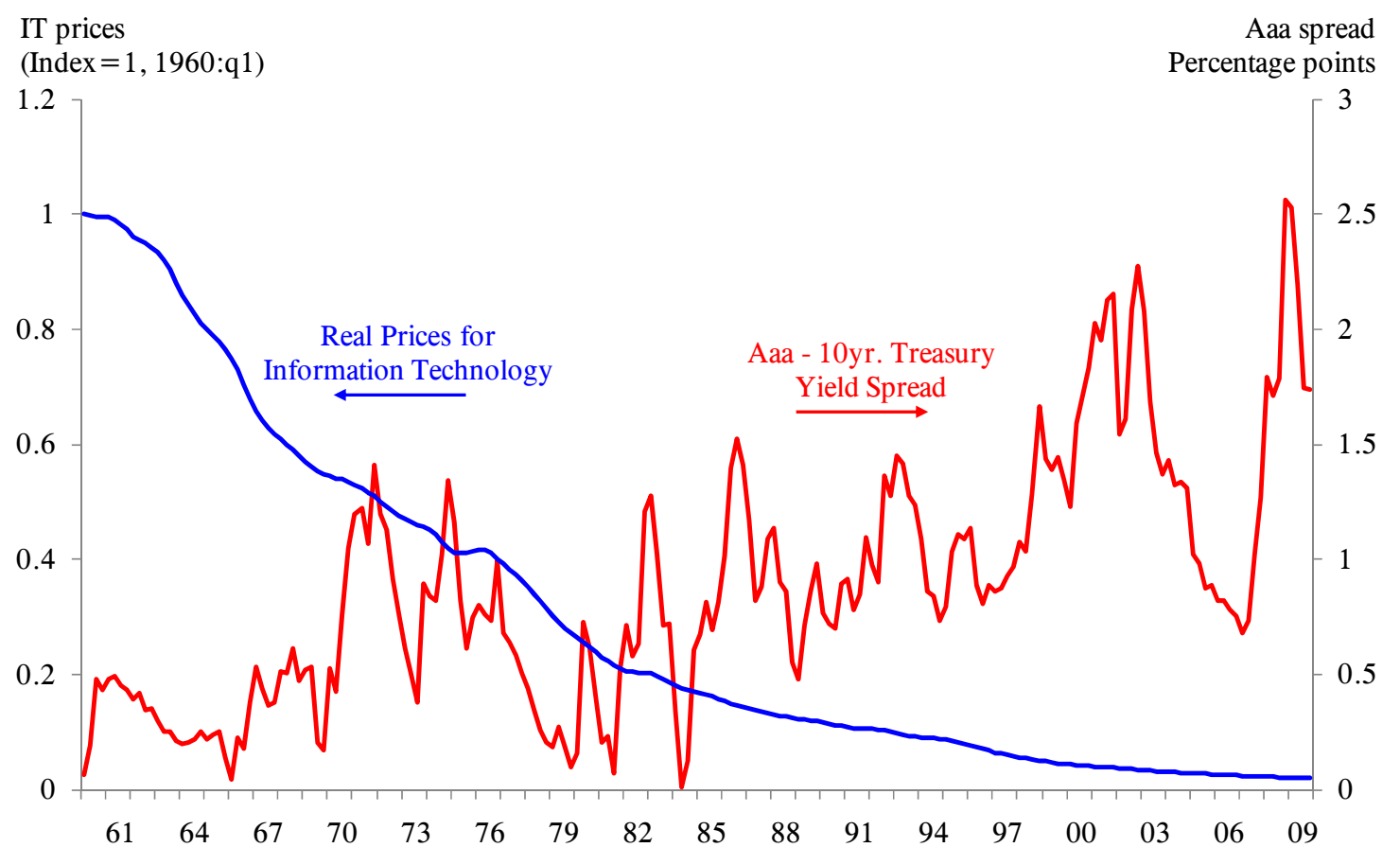




\section{Tracking the Burden of Capital Requirements}

For the longer-sample models of $C P F C$, there is a need to account for shifts in capital requirements on banks, with higher burdens expected to increase the security-funded share of business credit. To control for the Basel 1 capital standards, a 0-1 variable equal to 1 between the 1990q1 implementation of the Basel 1 capital accords up through the 2006:q2 announcement of how the Basel 2 capital requirements were to be implemented by U.S. regulators (BasellAnn). Since Basel 1 implies higher burdens on banks, BasellAnn is expected to have a positive sign (see Bernanke and Lown (1991) and Berger and Udell (1994) on Basel 1's role in the credit crunch of the early 1990s).

Although the international accord on Basel 2 was announced in 2004, U.S. regulators delayed implementation and delayed announcing details about how it would be implemented in the U.S. until the spring of 2006. To control for Basel 2, a 0-1 variable (Basel2Ann) equal to 1 since 2006:q2 was included in some cointegrating vectors (not shown). The separate treatment of Basel 1 and 2 is based on the view that the risk management provisions for very large banks effectively lowered the capital requirements from Basel 1 levels. This implies Basel 2 marked an aggregate easing of bank capital standards, particularly because the small number of banks eligible for using internal risk management models held the vast majority of bank loans in the U.S. by the mid-2000s. Accordingly, Basel2Ann is expected to have a less positive coefficient than Basel2Ann. In other runs not shown in the tables, 0-1 variables based on Basel announcement dates were tried, but performed less well than variables based on implementationdates. But Basel2Ann proved insignificant and is dropped from the models shown in Table 1. 


\section{Tracking Corporate Risk Premia}

In principle money market risk premia could proxy the liquidity benefits of the safety net to banks. However, in practice, simultaneity issues arise, especially after the Fed announced the commercial paper funding facility (CPFF) in late October 2008. Instead, liquidity and default risk are tracked by spreads between yields on Aaa-rated corporate and 10-year Treasury bonds (Aaa10TR) based on the view that this yield spread mainly reflects liquidity risk premiums. Yield spreads between A-rated corporate and default free Treasury bonds (A10TR) reflect a combination of swings in default and liquidity risk premiums (Jaffee, 1975). The former performed better in long-run, low-frequency quarterly models of $C P F C$, while the latter had information content in the higher frequency monthly models of CPBLMIX.

Wider spreads are less a threat to the funding of bank loans, as banks had access to insured deposits and Fed liquidity facilities before mid-October 2008. As a result, the price and non-price terms of commercial paper likely rise relative to those of bank loans, implying a negative relationship between the commercial paper share of short-term business credit and the corporate yield spread in levels and first differences (Figure 5). The Aaa-10 year Treasury yield spread jumped in late 2008 (Figure 4), nearing the highs of the Great Depression.

The 3-month TED (LIBOR- T-bill rate) spread is added to CPBLMIX regressions in case LIBOR market conditions notably affect the loan component of CPBLMIX. But because paper issuers usually have back-up bank lines of credit, LIBOR swings likely affect the mix variable less than corporate bond risk premia. ${ }^{2}$ Nevertheless there may be some marginal information in

\footnotetext{
${ }^{2}$ For global contagion in the LIBOR market, see Duca, Muellbauer, and Murphy (2010a). For the impact of Fed actions on the LIBOR market, see Armantier, et al. (2008), Williams and Taylor (2009), and Wu (2008). For information on Fed credit programs, see www.federalreserve.gov/newsevents/recentactions.htm, www.newyorkfed.org/markets/Forms_of_Fed_Lending.pdf, and www.federalreserve.gov/monetarypolicy/bst.htm.
} 
the TED spread since bond and TED spreads have moved differently (Figure 6). (This variable mattered more in monthly models than in quarterly models).

Figure 5: Changes in the Relative Use of Commercial Paper Usually

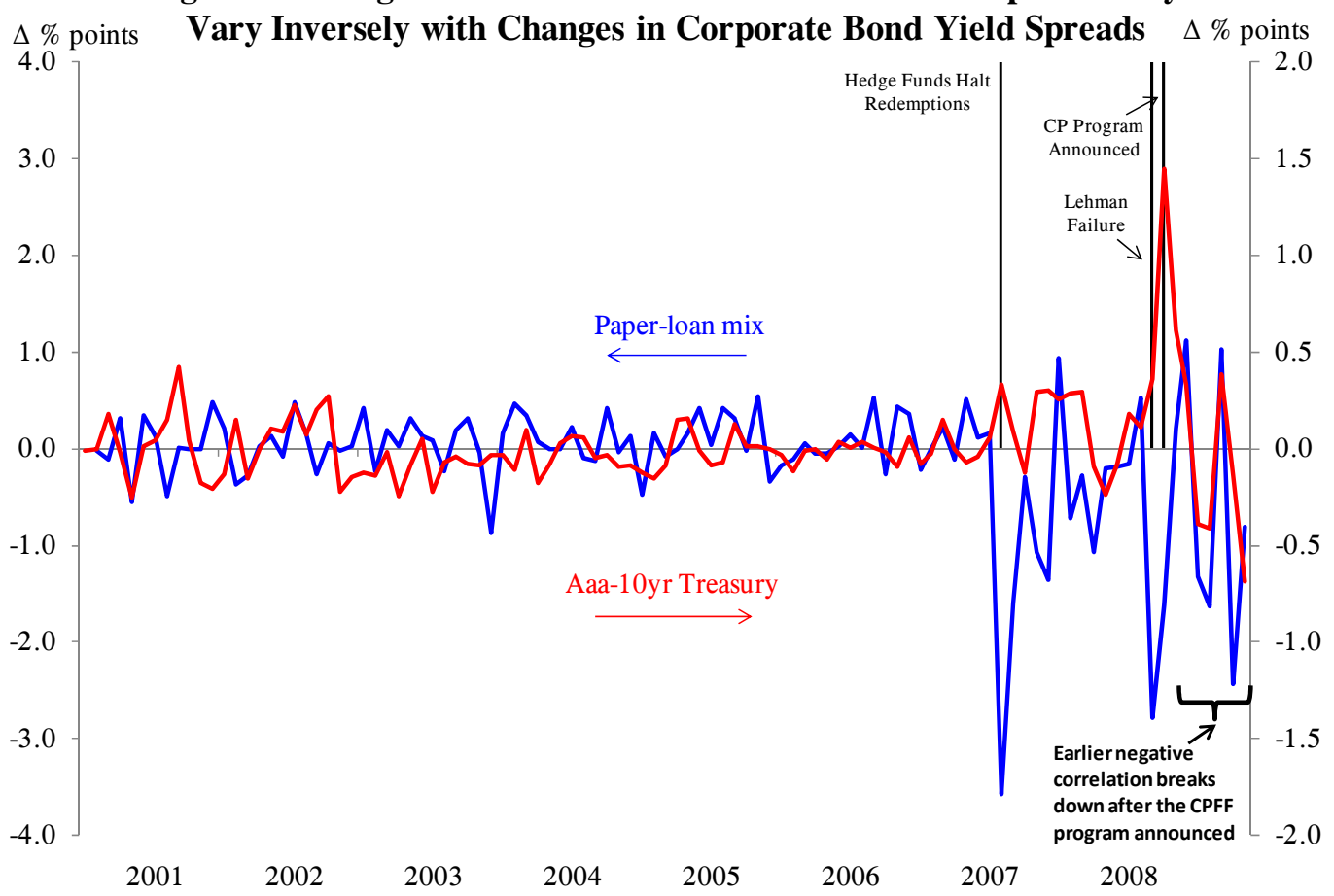

Figure 6: Libor and Bond Yield Spreads Not Perfectly Correlated

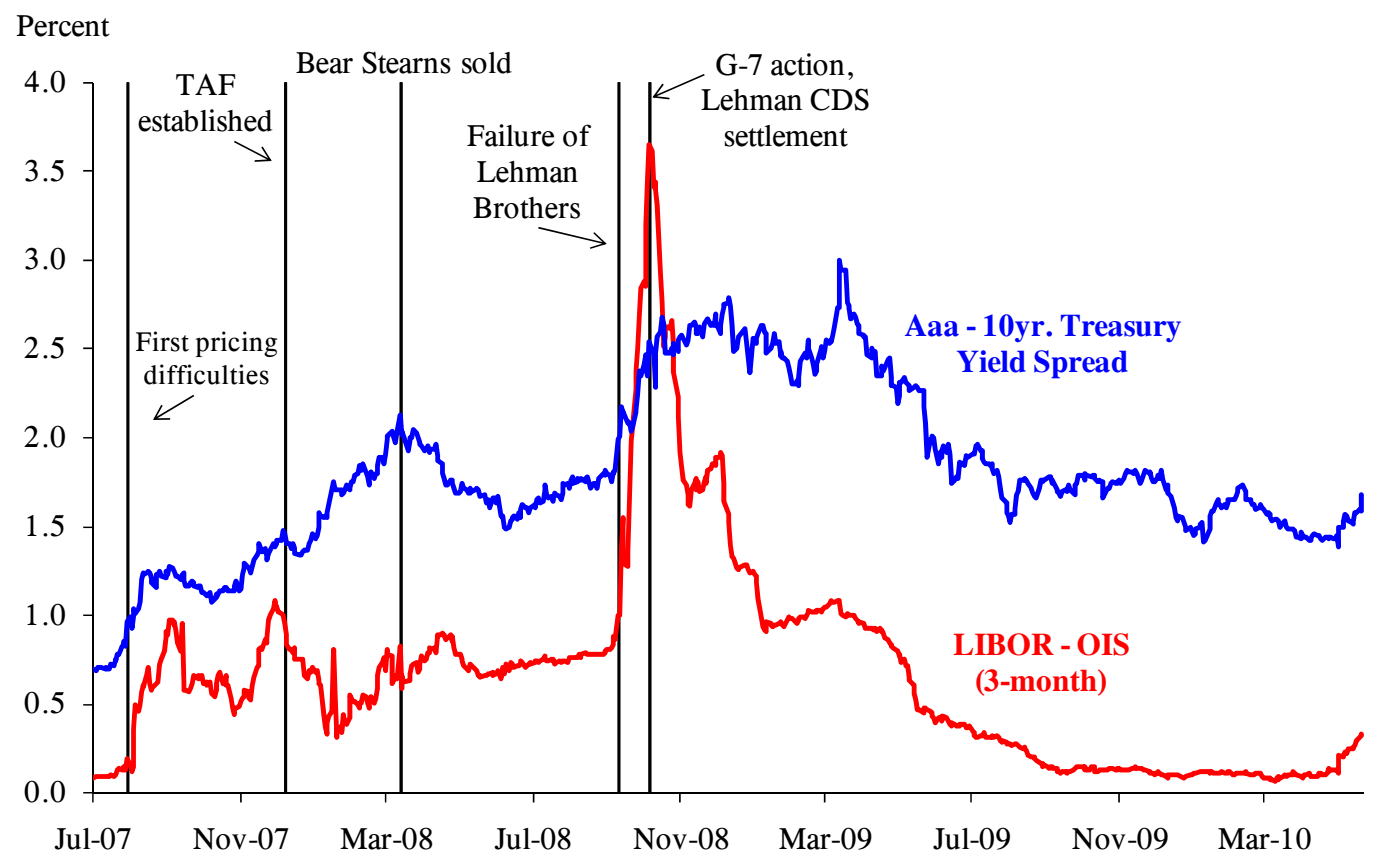




\section{Credit Market Intervention Variables}

To model the impact of Federal Reserve and Treasury actions and announcements, interactive variables are tested. Monthly variables multiply the change in a corporate bond yield spread (A10TR or Aaa10TR) and a dummy (FP) equal to 1 between October 2008 and July 2009, and 0 otherwise. The dummy is designed to proxy for the combined effects of three Federal Reserve and Treasury initiatives. The first was the Treasury's extension of deposit insurance to many money market mutual funds. The second was the Fed's decision to create a new funding facility that would lend to depository institutions in order for them to purchase ABCP from money funds experiencing significant redemption pressures. This was done to help prevent money-fund redemptions from setting off a disorderly sale of commercial paper into an unsettled also announced it would fund purchases of top-rated commercial paper via a new facility supported by the Treasury — the commercial paper funding facility $(C P F F)$ until January 2010.

market. Because this action was unlikely to fully alleviate increased uncertainty that firms might be unable to issue new paper to repay maturing debt if investors became too risk averse, the Fed

Under this back-stop facility, directly-issued three-month A1/P1-rated paper is purchased at a rate equal to the three-month OIS rate plus 100 basis points, and if the issuer provides insufficient collateral, OIS plus 200 basis points. Unsecured asset-backed, A1/P1-rated paper is purchased at a rate equal to the three-month OIS rate plus 300 basis points. Shortly following the announcement of the facility, the commercial paper-Treasury bill spread fell back toward normal levels (Figure 7). Owing to the penalty discount pricing, CPFF holdings of paper accumulated in a crisis will reverse with a short lag as a financial crisis unwinds. In this way, the CPFF has less marginal effect on the composition of credit when crisis conditions in the paper market return to normal. To capture this feature, the $0-1$ variable $(F P)$ equals 1 in the months 
(October 2008 to July 2009) or the quarters 2008:q4-2009:q3 when the Fed held at least 10 percent of total U.S.-issued commercial paper. In principle, the variable $F P$ may also capture market return to normal. To capture this, the $0-1$ variable $(F P)$ equals 1 in the months (October 2008 to July 2009) or quarters 2009:q1-2009:q2 (2008:q4 omitted owing to the use of the t-1 lag of liquidity premiums) when the Fed held at least 10 percent of total U.S.-issued commercial

\section{Figure 7: Commerical Paper Spreads Narrow Following Announced Fed Actions Affecting Money Funds and Commercial Paper}

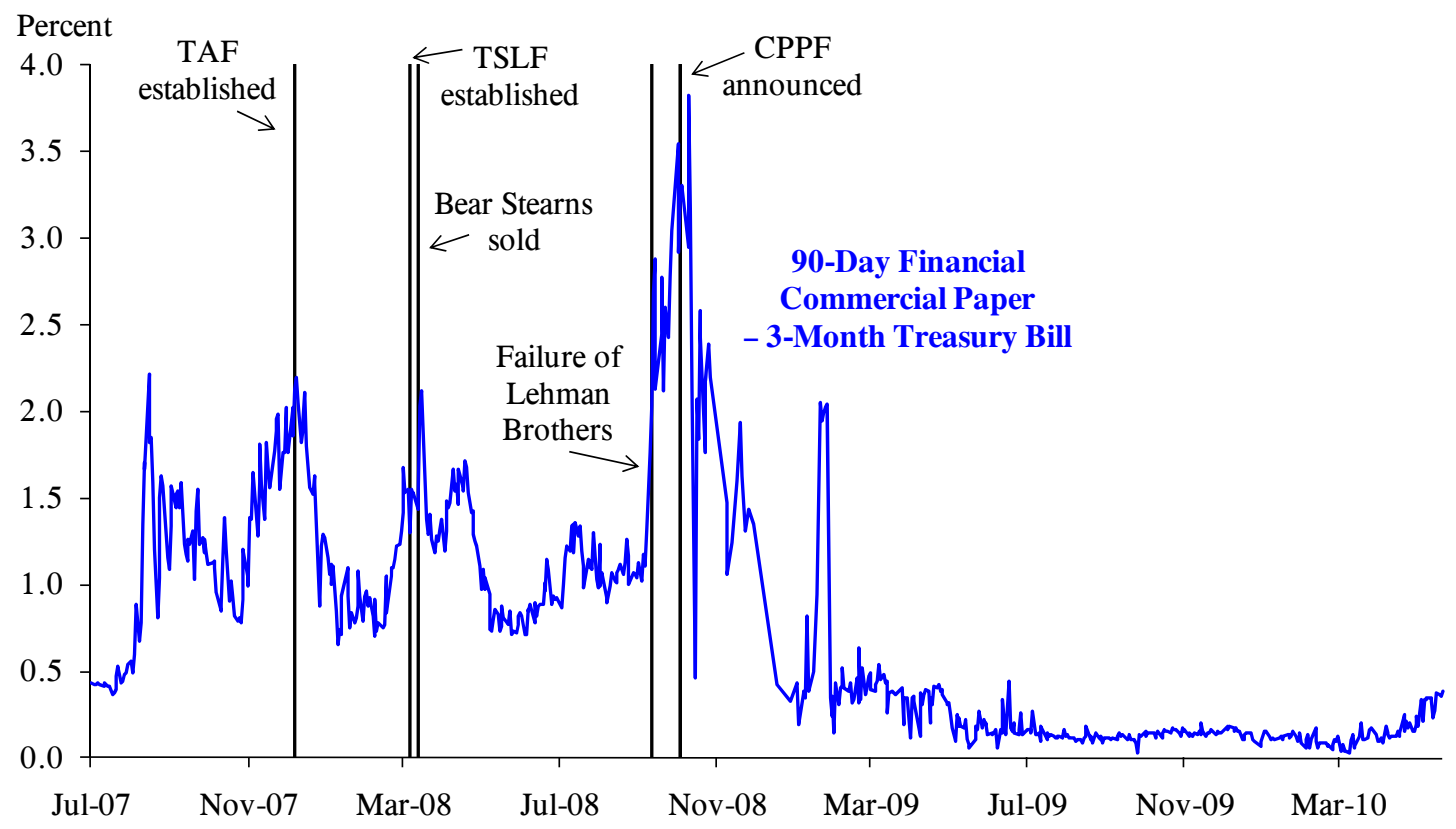

Note: Spreads based on prime (nonfinancial and financial) commercial paper rate until 1996; financial paper thereafter.

paper. In principle, the variable $F P$ may also capture other contemporaneous interventions, such as the FDIC's Temporary Liquidity Guarantee Program, TARP legislation, and capital injections. However, the fading of the CPFF to holding less than 10 percent of outstanding commercial paper in August 2009 is not contemporaneous with the ending of those programs. Furthermore, the interaction variable loses significance if the unwinding backstop feature of the CPFF is not taken into account by simply defining $F P$ to equal one in all months since October 2008, which 
would better align with the ongoing aspects of those of other facilities. Nevertheless, it is difficult to completely disentangle the effects of other facilities.

Reflecting that such actions may cushion the impact of higher liquidity and default risk pressures, the interactive term $F P * A 10 T R$ is expected to have a sign opposite from a noninteractive yield spread. These expected signs assume that the net effect of Fed and Treasury actions to improve money market and banking system conditions had larger short-run cushioning effects on commercial paper market than on bank loans, which, a priori, is an empirical issue.

Owing to the use of lower frequency data in the quarterly models, the impact of these programs is modeled by inter-acting the $\mathrm{t}-1$ level of the Aaa- $10 \mathrm{yr}$. Treasury yield spread with the t-1 lag of a quarterly dummy $F P Q$ that equals 1 over 2009:q4 2009:q2. This interactive variable either enters by itself or is subtracted from the Aaa-Treasury spread, which effectively zeroes out the spread during the intervention period. Another quarterly model also enters $F P Q$ as a non-interacted, intercept shift term.

Under another liquidity program, the Term Asset-Backed Securities Loan Facility (TALF) which was started after a long delay in March 2009 (announced in December 2009), the Fed purchases top-tier rated asset-backed medium-term debt that funds several types of loans, included business loans backed by the Small Business Administration, equipment loans, credit cards, student loans, and auto loans. In this program, issuers voluntarily approach the facility for funding after packaging such securities in accordance with the terms of the program. The start of TALF in March 2009 was accompanied by a revival of commercial paper issuance that later ebbed in April. Indeed, in all the models March 2009 was a large, positive outlier that largely unwound in April. Paper issuers and investors may have held misplaced hopes that the TALF would help improve liquidity conditions in the commercial paper market for two reasons. First, 
reports indicated that markets were disappointed by the low initial volumes of TALF purchases.

Second, and more importantly, the TALF was designed mainly to improve liquidity conditions in medium-term asset-backed securities used to fund consumer and business loans over the medium-, not the very short-run. The liquidity problems arising during the financial crisis has fostered some segmentation of securities markets (and was a major rationale for asset market interventions by the Fed and Treasury) that plausibly limited spill-over effects of the TALF on the commercial paper market. Some monthly models include, $\triangle T A L F$, equal to 1 in March 2009, -1 in April, and 0 otherwise. Comparing models 3 with 4 and models 7 with 8 , including $\triangle T A L F$ cleans up residuals without altering key coefficient estimates other than the TED spread.

\section{Quarterly Regulation Q Disintermediation and Deregulation Variables}

During the era of Regulation Q ceilings on deposit rates offered by banks, banks lost market share to commercial paper and security funded lenders when market interest rates rose above deposit rate ceilings. The inability of banks to offer interest rates in line with market interest rates induced households and other investors to shift funds out of banks, thereby inducing banks to tighten their credit standards, consistent with the findings of Duca, Muellbauer, and Murphy (2010b). One variable to track these effects is Duca's (1996) measure of how much Regulation Q ceilings on deposit interest rates were binding until Regulation Q ceilings were lifted in the early 1980s. $R E G Q$ controls for short-run disintermediation effects not tracked by interest rates or measures of the user cost of capital (Duca and Wu, 2009), which are likely to increase the security-funded share of credit at the expense of the bank-funded share.

One innovation around these ceilings was the creation of money market mutual funds (MMMFs) in 1971 in the U.S. which could pay market-determined interest rates. These funds were not really notable until about 1973 and check-writing features on MMMFs for households 
were introduced in the late spring of 1974 by Fidelity. By giving investors an option to purchase a more liquid form of commercial paper, the rise of money market funds lowered the costs of funding commercial paper and other forms of open market paper relative to banks. Partly to counteract this drain on the banking system, banks were allowed to offer money market deposit accounts starting in 1982:q4. This resulted in inflows into bank deposits from both MMMFs and other assets that were large enough to positively affect money demand (Duca, 2000) and the availability of bank loans (see Aron, et. al, 2010). To control for these two innovations in a parsimonious way, a variable (MMAdvantage) is included that equals 1 over 1974:q3-1982:q3, a period when security-funded business credit was positively affected by the presence of MMMFs and the absence of MMDAs. In addition, because MMDAs received inflows from nonMMMF assets, an additional dummy ( $D M M D A)$, equal to 1 in 1982:q4, is included to control for substitution from non-MMMF sources when MMDAs first became available.

\section{Monthly Event Risk and Inventory Variables}

To handle unusual event risks that boosted liquidity risk in the short-sample monthly models, these models include a dummy ( $A$ ug $9=1$ in 2007:08, $=0$ otherwise) for the market reaction to the August 9, 2007 decision by some European hedge funds to halt redemptions, owing to the lack of market trades on their subprime mortgage-related assets. This induced a surge in LIBOR-OIS and LIBOR-Treasury spreads that was not immediately picked up by a surge in corporate bond yield spreads or the t-1 lag of the TED spread. On similar grounds, a dummy for the September 2008 failure of Lehman (Lehman $=1$ in 2008:09, 0 otherwise) is also included. Finally, reflecting that commercial paper issuance (and hence CPBLMIX) is more dependent on the need to finance inventories (Kashyap, Wilcox, and Stein, 1993), regressions also included the log of the monthly ISM purchasing managers' (manufacturing) index of 
inventory demand, which tracks the change in inventories and is more timely than inventoryshipment ratio data and much less subject to revisions (LINVISM). In the "broad mix" alternative, the ISM index for inventories is replaced with the log of the overall ISM index $(L I N V)$, which is more reflective of manufacturing output in general. This is advantageous because the consumer loan component of bank loans is linked to consumer spending, particularly on manufactured items that are in the credit-sensitive durable part of consumer spending. Note that the timing of the ISM survey is early in a month, and tends to reflect activity in month t-1 (Harris, 1991). Thus, simultaneity is not much of an issue since using the time $t$ dated index essentially reflects activity in period t-1. Furthermore, the index is used as a scaling variable to control for the influence of inventory swings on the mix variable.

In the short monthly sample in which commercial paper data are consistently defined (2001:01-09:09), the paper-mix and bond yield spread variables are I(2), reflecting that at the sample's end, the paper mix plunges while the bond yield spreads soar, leading to serial correlation in both levels and first differences at the sample's end. To limit such distortions, the models regress first differences of the paper-loan mix on first differences of yield spreads for lags t-1 through t-3 in the presence of control variables (Aug9, Lehman, and LINVISM/LISM). In quarterly models, the one-quarter lag of the first difference of the quarterly average level of this index had the largest information content of the quarterly permutations tried.

\section{Results From Quarterly Models of the Security-Funded Short-Run Credit Mix (CPFC)}

Cointegration models of the security-funded short-run credit mix variable $(C P F C)$ were run owing to unit roots in $\mathrm{CPFC}$, the reserve requirement tax, and the information technology price series. Four models are presented which have a common sample period of 1961:q1- 
2009:q4 to avoid sample breaks in the 1950s data from changes in Flow of Funds sampling and methodological steps.

As shown in the upper-panel of Table 1, all four models include the reserve requirement tax and the real price of information technology as long-run endogenous variables in the cointegrating vector. Because some regulatory variables were long-lasting, namely BasellAnn (t1 and MMAdvantage(t-1)), they were included in the cointegrating vector to more accurately gauge long-run relationships. With the exception of how credit market intervention variables are modeled, the same set of short-run exogenous variables are included to handle shorter term regulatory effects $(R E G Q(\mathrm{t}-2)$ and $D M M D A(\mathrm{t})$, and the stationary (Aaa-10 yr. Treasury bond yield spread to control for short-run shocks in liquidity risk premiums.

The models differ in how they model credit market interventions by the Fed and Treasury. The baseline model (Model 1) ignores these interventions. The second model essentially assumes that the Fed's CPFF program effectively neutralized any effect of liquidity risk in 2009:q1 and 2009:q2. It replaces the Aaa-Treasury spread with the difference between Aaa10TR and Aaa10TR multiplied by the dummy FPQ, which equals 1 in the first two quarters of 2009. The third model retains Aaa10TR, but adds the product, Aaa10TR*FPQ as a separate variable. The fourth model simply adds $F P Q$ as a stand-alone variable.

Each model is estimated using Johansen $(1991,1995)$ procedure to estimate cointegrating vectors for the log-level of $\mathrm{CPSH}$ in the first stage, from which error-correction terms are constructed for use in a second step VAR in first differences for modeling short-run movements (log first differences) in $\mathrm{CPSH}$. For each model unique and statistically significant cointegrating vectors are estimated, allowing for deterministic trends in the long-run variables, but not in the cointegrating vector. All models used a lag length of 6 quarters that yielded 
significant and unique cointegrating vectors and clean residuals, and minimized the AIC statistic. Note that unique and significant vectors can be found allowing for linear and quadratic time trends in the cointegrating vector and also not allowing for any time trend in the vector nor deterministic trends in the long-run variables. In each model, the implied equilibrium relationships indicate a statistically significant and positive relationship between the reserve requirement tax and the nonbank share of lending to nonfinancial businesses. As expected, the Basel 1 and money fund advantage variables had statistically significant and positive coefficients. Also, as expected, there is a negative relationship between the real price of information technology and the nonbank share of business credit. Higher IT prices suggest that information is more costly and transactions costs are higher, ceteris paribus. By implication, bank informational and transactions cost advantages over nonbank intermediaries are greater as IT prices are higher.

The short-run models of the change in the nonbank share of business credit take into account the long-run relationships by including an error-correction term equal to the t-1 gap of the actual level of security-funded debt share minus the estimated long-run equilibrium. Across the short-run models shown in the lower-panel of Table 1, the error-correction coefficients are highly significant, with an expected negative sign. Thus, if actual nonbank share exceeded its equilibrium in time $t-1$, this would exert a negative impact on the time $t$ change in the nonbank share, as one would expect. The speeds of adjustment are similar, implying that roughly 20 percent of disequilibria are eliminated on average per quarter. This speed is sensible given the large structural shifts in the security market-funded share of business credit over the past 5 decades. The regulatory variables are all significant with the expected signs. The disintermediation $(R E G Q)$ had significantly negative effects on the security market-funded share 
of nonfinancial business credit. Finally and as expected, the wider liquidity premium spreads as reflected in the Aaa-10 yr. Treasury spread have a negative effect, which is on the border of significance or marginal significance across the four models.

Using the estimates from the cointegrating vector for the baseline model (model 1) and adding the implied long-run effects of the other variables (coefficient divided by the speed of adjustment-i.e., the coefficient on the EC term), one can construct an implied equilibrium share of security-funded lending. This is done using the baseline model. As shown in Figure 8, this equilibrium series lines up well with the actual log share, and tends to slightly lead it, consistent with the sign of the error-correction term.

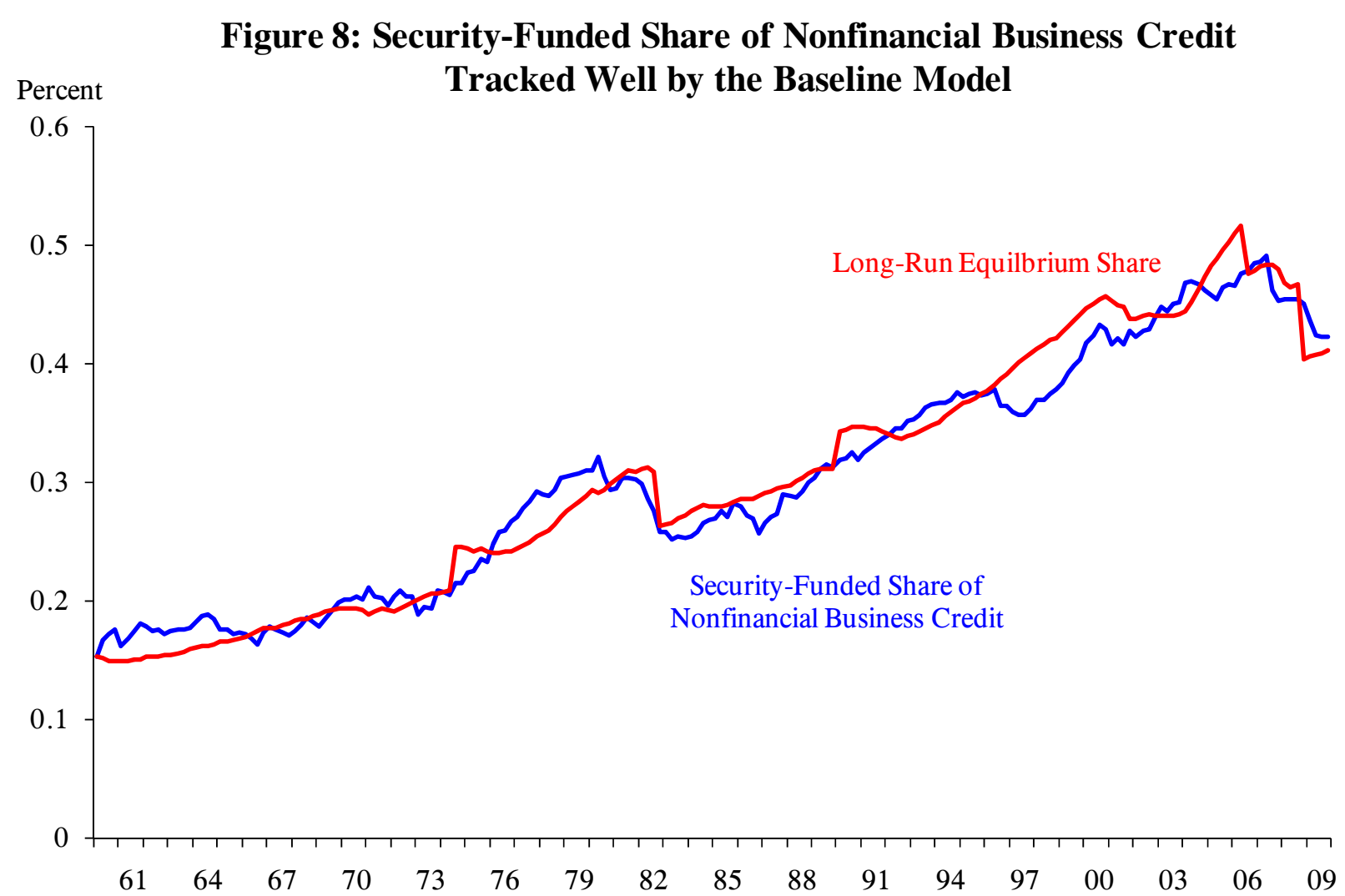

With respect to the impact of the policy interventions, quarterly evidence indicates that any detectable effects were weak. In model 2 , the liquidity spread that is directly adjusted with 
the CPFF dummy is barely more significant than the regular spread in model 1, with barely any improvement in fit and perhaps a slightly faster speed of adjustment. In model 3, which includes the regular Aaa spread and the spread multiplied by the FPQ intervention dummy, the interactive term is positive, but statistically insignificant. This indicates that only a weak effect could be detected. In model 4 , the speed somewhat faster than those of models 1-3. However, the separately entered FPQ variable, while positive, is not statistically significant.

Overall, quarterly results suggest that the policy interventions did little to stabilize the security-funded share of nonfinancial business debt. Nevertheless, the Fed actions were primarily geared towards aiding the commercial paper market, and thus should probably not be gauged by their detectable effects on the security-funded debt share used in this paper. Furthermore, the quarterly models suffer from having a low frequency. More specifically, any policy intervention effects could only be identified with limited degrees of freedom using this sample (really just 2 out of nearly 200 quarterly observations) and these interventions were not really tried before in the U.S. For this reason, models using monthly data and that are more focused on the relative use of commercial paper are more suitable to assess the impact of the money market interventions by the Fed and the Treasury. The long-horizon models do, however, establish that liquidity risk can negatively affect the reliance of businesses for loans from security-market funded sources which lack(ed) the government safety net backing bank funding.

\section{Results From Monthly Models of the Paper-Bank Loan Mix During the Crisis}

Table 2 presents eight monthly regressions based on eq. (2) using different sample periods and mix definitions, and which use first differences of the yield spread between A-rated corporate and $10 \mathrm{yr}$. Treasury bonds. Table 3 presents similar results using first differences of the Aaa-Treasury spread, and in general, the qualitative results are similar but the model fits are 
tighter using the A-Treasury spread. The results in Table 2 are more comparable in this dimension to the results of the related study of the Great Depression (Duca, 2010), while those from Table 3 are similar to the results in section 3 of this study that use the Aaa-Treasury spread. Note that the qualitative findings in Table 1 were also unchanged when the A-Treasury spread replaced the Aaa-Treasury spread (table available upon request).

The discussion will focus on Table 2's results. Models (1)-(4) use the narrow mix variable (CPBLMIX), while models (5)-(8) use broader (CPBCLMIX) index and the broader ISM index, but otherwise correspond to models (1)-(4) with respect to sample periods and variables. Model 1 covers the sample through October 2008 and omits controls for Federal Reserve and Treasury programs. The ISM indexes have positive, but not always significant coefficients. ${ }^{3}$ As expected, the t-1 and t-3 lags of $\triangle A T R$ are negative and significant (the t-2 lag is insignificant) in Model 1, as are the financial crisis dummies (Aug9 and Lehman). However, extending the sample to September 2009, the t-1 lag of $\triangle A T R$ is no longer significant in Model 2. This change suggests that the CPFF affected the impact of risk premiums on the relative use of commercial paper and bank loans.

To shed more light on that hypothesis, models $3,4,7$, and 8 are estimated over the full sample and include a $0-1$ variable $(F P)$ for the liquidity programs multiplied by $\triangle A T R$. The inclusion of these terms yields non-interactive rate spread coefficients that are similar to those in samples ending in October 2008, and interactive rate spreads $\left(F P^{*} \triangle A T R\right)$ that are jointly significant. In particular, the interactive rate spread coefficients at lags $\mathrm{t}-1$ and $\mathrm{t}-3$ are highly statistically significant and oppositely signed from the non-interactive rate spreads, consistent

\footnotetext{
${ }^{3}$ Note that owing to little variation in the inventory diffusion index in the short sample ending in 2008:08, it is difficult to identify an effect of inventories. However, in the longer sample, the inventory variable mainly has a positive and at least marginally statistically significant coefficient, consistent with the general use of commercial paper to finance working capital (such as inventories) and the results of Kashyap, Wilcox, and Stein (1993).
} 
with liquidity programs having a desired effect. One caveat is that March 2009 is a big enough positive outlier, that there is evidence of serial correlation in the residuals for all the full sample models $(2,3,6$, and 7$)$ that omit the TALF program variable. This problem appears corrected by the presence of the $\triangle T A L F$ variable in the interactive-spread models (4 and 8). The overall patterns of results suggest that the Federal Reserve and Treasury liquidity programs have helped stabilize the relative use of commercial paper by countering the influence of wider liquidity and default risk premiums. Nevertheless this interpretation and the findings as a whole should be viewed with caution in light of the short sample, which makes it infeasible to estimate errorcorrection models using monthly data with cointegration techniques that may more fully reflect the short- and long-run influences of securities market conditions on credit flows.

During the early 1930s, the Federal Reserve did not actively intervene in commercial paper purchases when commercial paper plunged in tandem with rising corporate liquidity and default risk premiums, even after it was granted discretion to do so in the summer of 1932 in an amendment (section 13(3)) of the Federal Reserve Act. In contrast to that episode, the Federal Reserve has intervened to provide liquidity in the commercial paper market during the current crisis, especially since October 2008. By itself, the evidence from this sub-section is subject to major qualifications owing to the short monthly sample. Nevertheless, when combined with the previous sub-section's findings from long quarterly samples covering nearly one-half century, the overall results are consistent with the hypothesis that money market interventions helped stabilize the use of commercial paper by countering rising corporate risk premiums.

\section{Conclusion}

This study analyzes money market conditions during the current financial crisis, partly drawing on some limited parallels with the collapse of commercial paper use during the Great 
Depression. Consistent with Bernanke (1983) and the pre-World War II studies of Kimmel (1939) and Young (1932), evidence in a related study (Duca, 2009) indicates that the provision of credit shifted towards debt whose funding sources were less vulnerable to liquidity shocks associated with swings in credit risk premia during the Great Depression. The findings are also consistent with the view that changes in financial technology, regulations, and risk premia on private debt affect the relative use of traditional deposit funded loans and nontraditional sources of credit as stressed in various strands of the money and banking literature (Mishkin, 2009; Greenbaum and Kanatas, 1982; and Adrian and Shin, 2009a, inter alia). And from a broader perspective, results provide additional empirical support for Adrian and Shin's (2009b) emphasis that "banking and capital market developments are inseparable."

The findings of the current study illustrate the continued importance of analyzing the composition of short-term business credit—especially during the recent financial crisis. In particular, up until the Fed and Treasury actions of October 2008, when corporate-Treasury bond yield spreads rose, the use of security-markets funded commercial paper fell relative to bank business loans, which could be funded with insured deposits. This linkage broke down after Fed and Treasury's announcements to buy commercial paper, provide discount loans to money market funds, and insure money market fund accounts. The pre-October 2008 pattern and the ensuing break from it suggest that the 2008 pullback in commercial paper outstanding owed to spikes in default and liquidity premiums. This interpretation is plausible because higher risk premiums on commercial paper are amenable to being addressed by the money market interventions of the Fed and the Treasury. Thus far, these actions appear to have prevented an even sharper fall in commercial paper and helped foster a reversal of the jump in the commercial paper-Treasury bill spread after the failure of Lehman. 
Such an interpretation is qualified by the short sample available for analyzing monthly data and because the financial crisis is not yet over. Nevertheless, the monthly impacts of rate spread variables on the relative use of commercial paper were estimated in the presence of some controls for credit demand, and commercial paper volumes began rising during the summer of 2009. In addition, some of the beneficial effects of the commercial paper funding facility may be hard to disentangle from complementary effects of other efforts to bolster liquidity in credit markets. Nevertheless, the monthly evidence is consistent with findings from long quarterly samples spanning crises over the last 50 years that corporate credit risk premiums negatively affect the use of security-funded credit. The qualification is that these interventions had weak estimated effects using quarterly data that may be of too low a frequency to econometrically detect any quarterly effect. With appropriate caveats, findings suggest that new liquidity programs in the U.S. have, thus far, helped prevent the money markets from melting down by as fast as they did during the early 1930s. 


\section{References}

Adrian, Tobias and Hyun S. Shin (forthcoming), "Liquidity and Leverage," Journal of Financial Intermediation.

Adrian, Tobias and Hyun S. Shin (2009a), "Money, Liquidity, and Monetary Policy,” American Economic Review 99(1), 600-09.

Adrian, Tobias and Hyun S. Shin (2009b), "The shadow banking system: implications for financial regulation," Banque de France Financial Stability Review 13, 1-10.

Anderson, Richard B. and Rasche, Robert (2001), "Retail Sweep Programs and Bank Reserves, 19941999," Federal Reserve Bank of St. Louis Review, January/February.

Armantier, Olivier, Krieger, Sandra, and McAndrews, James, "The Federal Reserve's Term Auction Facility," Federal Reserve Bank of New York Current Issues in Economics and Finance, vol. 14, no. 5, July 2008.

Berger, Allen, and Gregory Udell (1994), "Did Risk-based Capital Allocate Credit and Cause a 'Credit Crunch' in the United States?" Journal of Money, Credit and Banking 26, 585-628.

Bernanke, Ben S. (1983), "Non-Monetary Effects of Financial Crises in the Propagation of the Great Depression," American Economic Review 71, 257-76.

Bernanke, Ben S. and Mark Gertler (1989), "Agency Costs, Net Worth, and Business Fluctuations," American Economic Review 79, 14-31.

Bernanke, Ben S., Gertler, Mark, and Simon Gilchrist (1996), “The Financial Accelerator and the Flight to Quality, Review of Economics and Statistics 58, 1-15.

Bernanke, Ben S., and Cara S. Lown (1991), "The Credit Crunch," Brookings Papers on Economic Activity 1991:2, 205-39. 
Diamond, Douglas W. (1991), "Monitoring and Reputation: The Choice Between Bank Loans and Directly Placed Debt,” Journal of Political Economy 91, 689-721.

Duca, John V. (1999), “An Overview of What Credit Market Indicators Tell Us,” Economic and Financial Review, Federal Reserve Bank of Dallas, 1999:Q3.

Duca, John V. (2000), "Financial Technology Shocks and the Case of the Missing M2," Journal of Money, Credit, and Banking, 32, 820-39.

Duca, John V. (2005), “Why Have Households Increasingly Relied on Mutual Fund Loads to Own Equity?" Review of Income and Wealth 51 (3), 375-96.

Duca, John V. (2009), "Preventing a Repeat of the Money Market Meltdown of the Early 1930s," Federal Reserve Bank of Dallas Working Paper No. 0904.

Duca, J. V., Muellbauer, J. and Murphy, A. (2010a), "Housing Markets and the Financial Crisis of 20072009: Lessons for the Future," Journal of Financial Stability 6, 203-17.

Duca, John V., Muellbauer, John, and Anthony Murphy (2010b), "How Financial Innovations and Accelerators Drive Booms and Busts in U.S. Consumption,” mimeo, Oxford University.

Duca, John V., DiMartino, Danielle, and Renier, Jessica (2009), “Fed Confronts Financial Crisis By Expanding Its Role As Lender of Last Resort,” Federal Reserve Bank of Dallas Economic Letter, February/March 2009. <http://dallasfed.org/research/eclett/2009/el0902.pdf $>$

Dutkowsky, Donald H. and Barry Z. Cynamon (2003), "Sweep Programs: The Fall of M1 and the Rebirth of the Medium of Exchange," Journal of Money, Credit, and Banking 35, 263-279.

Edwards, Franklin R. and Frederic S. Mishkin (1995), “The Decline of Traditional Banking: Implications for Financial Stability and Regulatory Policy,” New York Federal Reserve Economic Policy Review 1 (2), July. 
Federal Reserve Bank of St. Louis (2010), "Federal Reserve Board Data on OCD Sweep Account Programs," $<$ http://research.stlouisfed.org/aggreg/swdata.html>

Friewald, Nils, Jankowitsch, Rainer, and Subrahmanyam, Marti (2009), "Illiquidity or Credit Deterioration: A Study of Liquidity in the Corporate Bond Market during Financial Crises," mimeo, New York University and University of Vienna.

Goodhart, Charles I. (1987), “Why Banks Need a Central Bank,” Oxford Economic Papers 39(1), 75-89.

Gorton, Gary B. and Andrew Metrick (2009), "Securitized Lending and the Run on the Repo," Yale ICF Working Paper No. 09-14. Available at SSRN: http://ssrn.com/abstract=1440752.

Harris, Ethan, (1991), "Tracking the Economy with the Purchasing Managers' Index." Federal Reserve Bank of New York Quarterly Review 16, no. 3, 61-69.

Jaffee, Dwight M., and Franco Modigliani (1969), “A Theory and Test of Credit Rationing,” American Economic Review 59, 850-72.

Jaffee, Dwight M. (1975), "Cyclical Variations in the Risk Structure of Interest Rates,” Journal of Monetary Economics 1, 309-25.

Jaffee, Dwight M. and Thomas Russell (1976), “Imperfect Information, Uncertainty, and Credit Rationing," Quarterly Journal of Economics 90, 651-66.

Johansen, S. (1991), "Estimation and Hypothesis Testing of Cointegration Vectors in Gaussian Vector Autoregression Models," Econometrica 59, 1551-80.

Johansen, S. (1995), Likelihood-based Inference in Cointegrating Vector Autoregressive Models, Oxford: Oxford University Press.

Jorgenson, Dale W. and Kevin J. Stiroh (2007), “Information Technology and Growth (updated),” $<$ http://hdl.handle.net/1902.1/10670 UNF:3:LSIPIvbdHpXSzRzIz4zC4w== V1 [Version] > 
Kanatas, George and Stuart I. Greenbaum (1982), “Bank Reserve Requirements and Monetary Aggregates," Journal of Banking and Finance 6, 507-20.

Kashyap, Anil, Wilcox, David E, and Jeremy Stein (1993), "Monetary Policy and Credit Conditions: Evidence from the Composition of External Finance," American Economic Review 83, 78-98. Keeton, William R. (1979), Equilibrium Credit Rationing, New York: Garland.

Lang, William W., and Nakamura, Leonard I. (1995), " 'Flight to Quality' in Bank Lending and Economic Activity," with William W. Lang, Journal of Monetary Economics 36, 145-64.

Mishkin, Frederic S. (2009), The Economics of Money, Banking, and Financial Markets, 9th Edition, Addison-Wesley: New York.

Oliner, Stephen D. and Glenn D. Rudebusch (1996), "Monetary Policy and Credit Conditions: Evidence from the Composition of External Finance: Comment," American Economic Review 86(1), 30009.

Pennacchi, George G. (1988), ““'Loan Sales and the Cost of Bank Capital,” Journal of Finance 43 (2), $375-96$.

Schliefer, Andrei and Robert W. Vishny, "Unstable Banking,” Journal of Financial Economics 97, 306318.

Shockley, Richard L. (1995), “Bank Loan Commitments and Corporate Leverage,” Journal of Financial Intermediation 4, 272-301.

Stiglitz, Joseph E. and Andrew Weiss (1981), “Credit Rationing in Markets with Imperfect Information," American Economic Review 71, 393-410.

Williams, John C., and Taylor, John B. (2009), “A Black Swan in the Money Market,” American Economic Journal: Macroeconomics, vol. 1, no. 1, 58-83. 
Wu, Tao (forthcoming), “On the Effectiveness of the Federal Reserve's New Liquidity Facilities," The Review of Economics and Statistics. 
Table 1: Quarterly Error-Correction Models of the Change in the Security-Funded Share of NonFinancial Corporate Short-Term Debt (1961:2-2009:4, 9 quarter lag length)

\section{A. Long-Run Equilibrium Relationships: $\ln C P F C=\lambda_{0}+\lambda_{1} \ln R R T A X+\lambda_{2} \ln R P I T$}

Variable

Constant

$\ln R R T A X_{\mathrm{t}-1}$

$\ln R P I T_{\mathrm{t}-1}$

MMadvantage $_{\mathrm{t}-1}$

Basel1 t-1

Eigenvalue (1 vector)

Eigenvalue (2 vectors)

Trace Stat. (1 vector)

Trace Stat. (2 vectors)

Max-Eigen (1 vector)

Max-Eigen (2 vectors)
61:1-09:4 61:1-09:4 61:1-09:4 61:1-08:2

Model $1 \quad$ Model 2 Model 3 Model 4

$\begin{array}{llll}2.2681 & 2.2564 & 2.2406 & 2.2388\end{array}$

$0.0542^{* *}$

$0.0483^{* *}$

$0.0419^{* *}$

$0.0417^{* *}$

$(3.65)$

(3.36)

(2.76)

(2.76)

$-0.3239^{* *}$

$-0.3182^{* *}$

$-0.3106^{* *}$

$-0.3097^{* *}$

(-23.83)

$(-25.00)$

$(-25.55)$

$(-25.65)$

$0.1497^{* *}$

$0.1565^{* *}$

$0.1656^{* *}$

$0.1665^{* *}$

(5.04)

(5.59)

(6.27)

(6.34)

$0.1497^{* *}$

$0.0905^{* *}$

$0.0961^{* *}$

$0.0973^{* *}$

(5.04)

0.1769

$76.47190^{* *}$
$(3.26)$

0.1754

$(3.35)$

0.1751

0.0916

0.1055

$75.1256^{* * *}$

$73.4666^{* *}$

35.7288

$37.7378^{* *}$

$37.8031^{* *}$

18.8300

(3.40)

0.1754

0.0925

$73.9234^{* *}$

36.1162

$37.8072^{* * *}$

21.8611 19.0188

\section{B. Short-Run Equilibrium Relationships}

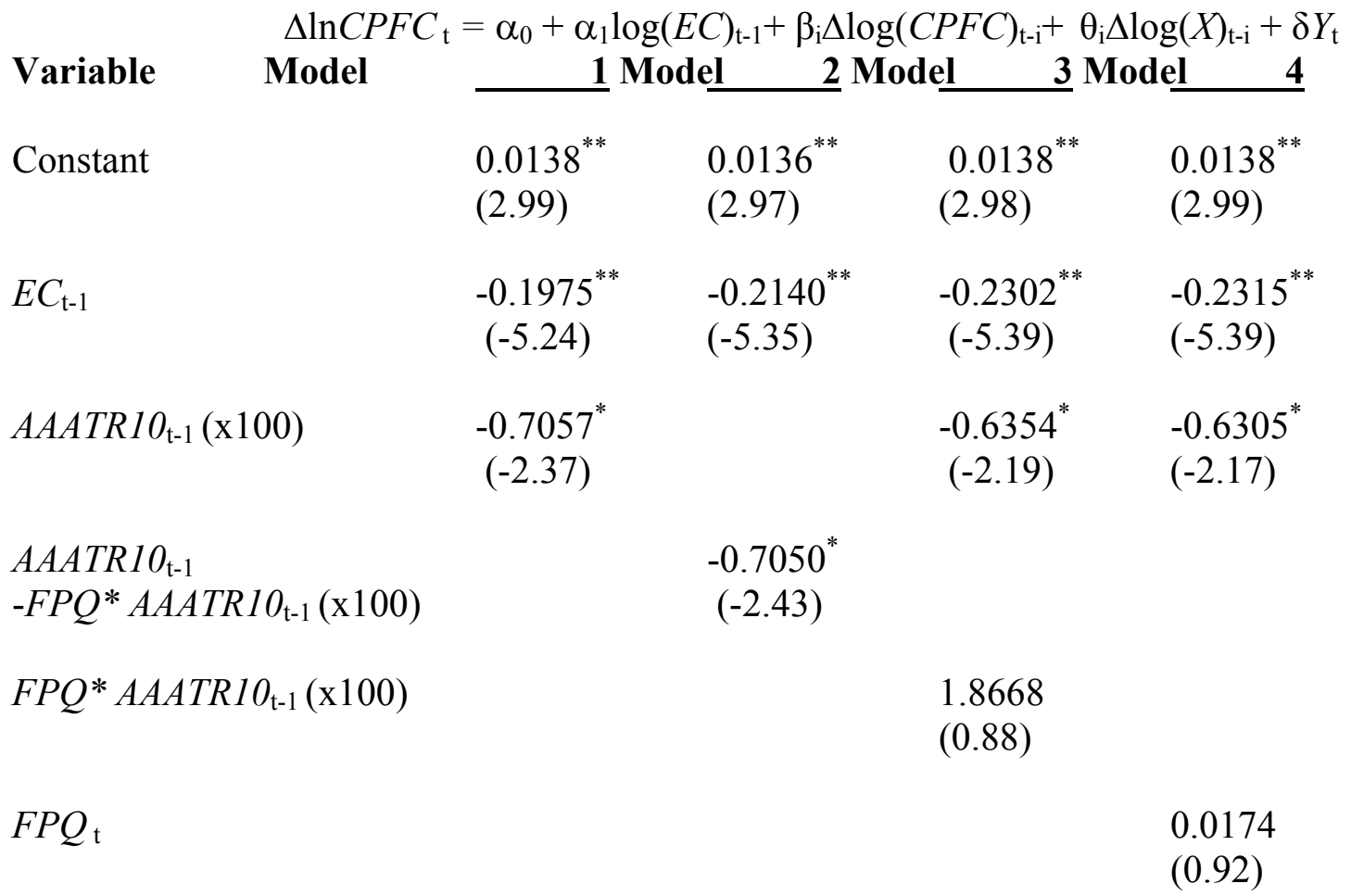




\begin{tabular}{|c|c|c|c|c|}
\hline$R E G Q_{\mathrm{t}-2}(\mathrm{x} 100)$ & $\begin{array}{l}0.8322^{* *} \\
(3.12)\end{array}$ & $\begin{array}{l}0.8158^{* *} \\
(3.06)\end{array}$ & $\begin{array}{c}0.7979^{* *} \\
(2.98)\end{array}$ & $\begin{array}{c}0.7952^{* *} \\
(2.97)\end{array}$ \\
\hline$D M M D A_{\mathrm{t}-1}$ & $\begin{array}{c}-0.0884^{* *} \\
(-4.29)\end{array}$ & $\begin{array}{l}-0.0882^{* *} \\
(-4.30)\end{array}$ & $\begin{array}{c}-0.0884^{* *} \\
(-4.29)\end{array}$ & $\begin{array}{l}-0.0887^{* *} \\
(-4.31)\end{array}$ \\
\hline$\Delta \operatorname{ISMINVENT}_{\mathrm{t}-1}(\mathrm{x} 100)$ & $\begin{array}{l}0.0546 \\
(1.16)\end{array}$ & $\begin{array}{c}0.0549 \\
(1.17)\end{array}$ & $\begin{array}{r}0.0576 \\
(1.22)\end{array}$ & $\begin{array}{r}0.0582 \\
(1.23)\end{array}$ \\
\hline Break1973q1 $1_{\mathrm{t}}$ & $\begin{array}{l}-0.0906^{* *} \\
(-4.08)\end{array}$ & $\begin{array}{l}-0.0901^{\text {** }} \\
(-4.08)\end{array}$ & $\begin{array}{l}-0.0903^{\text {** }} \\
(-4.06)\end{array}$ & $\begin{array}{l}-0.0903^{\text {** }} \\
(-4.06)\end{array}$ \\
\hline$\triangle \ln C P F C_{\mathrm{t}-1}$ & $\begin{array}{l}0.0222 \\
(0.29)\end{array}$ & $\begin{array}{r}0.0325 \\
(0.43)\end{array}$ & $\begin{array}{l}0.0436 \\
(0.57)\end{array}$ & $\begin{array}{r}0.0442 \\
(0.58)\end{array}$ \\
\hline$\triangle \ln C P F C_{\mathrm{t}-2}$ & $\begin{array}{l}0.1329^{+} \\
(1.91)\end{array}$ & $\begin{array}{l}0.1426^{*} \\
(2.05)\end{array}$ & $\begin{array}{l}0.1329^{*} \\
(2.19)\end{array}$ & $\begin{array}{l}0.1546^{*} \\
(2.20)\end{array}$ \\
\hline$\Delta \ln R R T A X_{\mathrm{t}-1}$ & $\begin{array}{l}0.0009 \\
(0.14)\end{array}$ & $\begin{array}{r}0.0010 \\
(0.14)\end{array}$ & $\begin{array}{l}0.0037 \\
(0.44)\end{array}$ & $\begin{array}{l}0.0035 \\
(0.43)\end{array}$ \\
\hline$\Delta \ln R R T A X_{\mathrm{t}-2}$ & $\begin{array}{l}0.0050 \\
(0.68)\end{array}$ & $\begin{array}{r}0.0050 \\
(0.68)\end{array}$ & $\begin{array}{l}0.0076 \\
(0.90)\end{array}$ & $\begin{array}{l}0.0074 \\
(0.89)\end{array}$ \\
\hline$\Delta \ln R P I T_{\mathrm{t}-1}$ & $\begin{array}{l}-1.1485^{* *} \\
(-2.66)\end{array}$ & $\begin{array}{c}-1.1703^{* *} \\
(-2.72)\end{array}$ & $\begin{array}{l}-1.1764^{* *} \\
(-2.72)\end{array}$ & $\begin{array}{c}-1.1724^{* *} \\
(-2.72)\end{array}$ \\
\hline$\Delta \ln R P I T_{\mathrm{t}-2}$ & $\begin{array}{l}0.7690 \\
(1.20)\end{array}$ & $\begin{array}{l}0.7780 \\
(1.22)\end{array}$ & $\begin{array}{l}0.7833 \\
(1.23)\end{array}$ & $\begin{array}{l}0.7829 \\
(1.22)\end{array}$ \\
\hline Adjusted $\mathrm{R}^{2}$ & .4208 & .4247 & .4228 & .4229 \\
\hline S.E. & 0.0184 & 0.0183 & 0.0183 & 0.0183 \\
\hline VECLM(1) & 25.28 & 25.40 & 26.01 & 26.31 \\
\hline VECLM(8) & 24.79 & 24.66 & 23.04 & 23.29 \\
\hline
\end{tabular}

Unit Root Tests (1958:q1-2009:q4)

Level (SIC lag $\quad 5 \%$ Critical $\quad 1 \%$ Critical

\begin{tabular}{|c|c|c|c|}
\hline & in parentheses) & level for lag & level for lag \\
\hline $\ln C P F C$ & -2.986601 & -3.431576 & -4.002786 \\
\hline$\triangle \ln C P F C$ & $-4.778380^{* *}(4)$ & -3.431576 & -4.002786 \\
\hline $\ln$ AaaTR 10 & $-6.357207^{* *}(0)$ & -3.431576 & -4.002786 \\
\hline $\ln R R T A X$ & -0.036425 & -3.431682 & -4.003005 \\
\hline$\Delta \ln R R T A X$ & $-12.91896^{* *}(3)$ & -3.431789 & -4.003226 \\
\hline $\ln R P I T$ & 0.213507 & -2.875262 & -3.461783 \\
\hline$\Delta \ln R P I T$ & $-3.071184^{*}$ & -2.875898 & -3.461783 \\
\hline
\end{tabular}

Notes:. ${ }^{*}$, and ${ }^{* *}$ ) denotes significant at the $90 \%, 95 \%$, and $99 \%$ level respectively. $\mathrm{t}$-statistics in parentheses. A lag length of 9 minimized the AIC, and yielded clean residuals and unique, significant vectors allowing time trends in the variables. Lag lengths for unit root tests are based on the SIC. Constant and trend significant and included in tests for $\ln C P F C$ and $\ln R R T A X$; for tests of $\ln R P I T$ the constant was significant and included, whereas the trend was insignificant and omitted. Coefficients on lags of difference terms longer than $\mathrm{t}-2$ are omitted to conserve space. 

Table 2: Monthly Models of the Change in the Commercial Paper-Bank Loan Mix (All sample periods start in 2001:02)

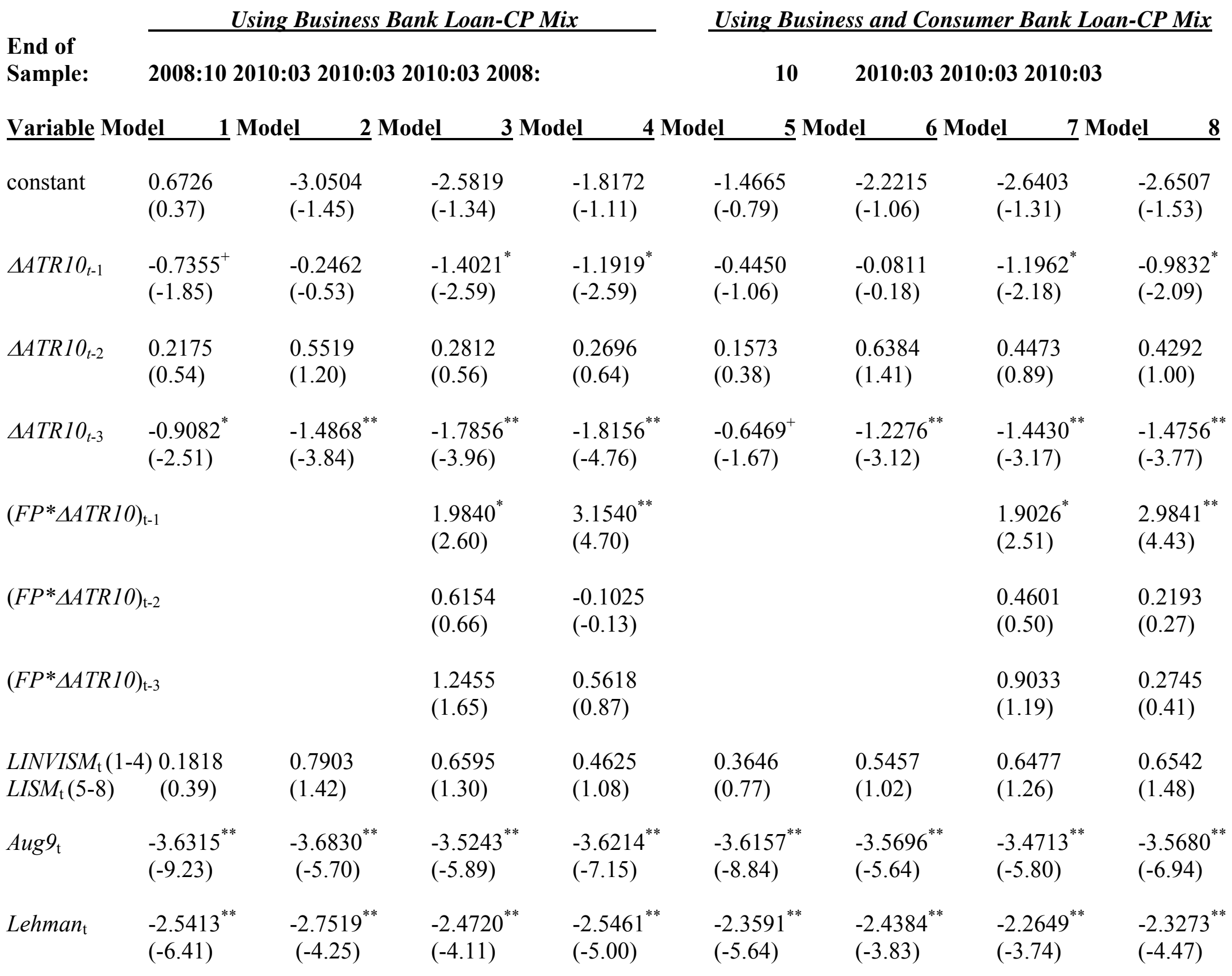




\begin{tabular}{|c|c|c|c|c|c|c|c|c|}
\hline$\triangle T E D_{t-1}$ & $\begin{array}{l}-0.4195^{+} \\
(-1.93)\end{array}$ & $\begin{array}{l}-0.3297 \\
(-1.23)\end{array}$ & $\begin{array}{l}-0.1788 \\
(-0.64)\end{array}$ & $\begin{array}{l}-0.4893^{*} \\
(-2.04)\end{array}$ & $\begin{array}{l}-0.3577 \\
(-1.58)\end{array}$ & $\begin{array}{l}-0.2300 \\
(-0.87)\end{array}$ & $\begin{array}{l}-0.1251 \\
(-0.45)\end{array}$ & $\begin{array}{l}-0.4268^{+} \\
(-1.75)\end{array}$ \\
\hline$\triangle T A L F_{t-1}$ & & & & $\begin{array}{l}2.5175^{* *} \\
(6.36)\end{array}$ & & & & $\begin{array}{l}2.4162^{* *} \\
(6.02)\end{array}$ \\
\hline $\begin{array}{l}\text { F-Test all } \\
\text { three lags of } \\
(\triangle A T R 10)_{\mathrm{t}-\mathrm{i}}\end{array}$ & $3.46^{*}$ & $5.09^{* *}$ & $9.48^{* *}$ & $12.41^{* *}$ & 1.27 & $3.33^{*}$ & $5.38^{* *}$ & $6.75^{* *}$ \\
\hline $\begin{array}{l}\text { F-Test all } \\
\text { three lags of } \\
\left(F P^{*} \triangle A T R 10\right)\end{array}$ & & & $6.48^{* *}$ & $11.45^{* *}$ & & & $5.02^{* *}$ & $9.30^{* *}$ \\
\hline $\mathrm{R}^{2}$ (corrected) & .595 & .338 & .432 & .594 & .555 & .320 & .392 & .552 \\
\hline S.E. & 0.3847 & 0.6364 & 0.5894 & 0.4985 & 0.3999 & 0.6235 & 0.5896 & 0.5062 \\
\hline $\operatorname{LM}(2)$ & 0.17 & 2.64 & 2.52 & 0.05 & 0.40 & 1.68 & 1.59 & 0.38 \\
\hline $\mathrm{Q}(4)$ & 4.60 & $18.41^{* *}$ & $22.07^{* *}$ & $8.77^{+}$ & 5.13 & $16.75^{* *}$ & $18.83^{* *}$ & 6.88 \\
\hline $\mathrm{Q}(12)$ & 15.22 & $23.72^{*}$ & $28.32^{* *}$ & 12.01 & 17.32 & $23.68^{*}$ & $26.49^{* *}$ & 13.40 \\
\hline
\end{tabular}

t-statistics in parentheses. $\left.{ }^{*}{ }^{* *+},+\right)$ significant at the 5- $(1-, 10-)$ percent level. 
Table 3: Monthly Models of the Change in the Commercial Paper-Bank Loan Mix Using Aaa-Treasury Spread (All sample periods start in 2001:02)

\begin{tabular}{|c|c|c|c|c|c|c|c|c|}
\hline \multirow{3}{*}{$\begin{array}{l}\text { End of } \\
\text { Sample: } \\
\text { Variable Mode }\end{array}$} & \multicolumn{4}{|c|}{ Using Business Bank Loan-CP Mix } & \multicolumn{4}{|c|}{ Using Business and Consumer Bank Loan-CP Mix } \\
\hline & \multicolumn{4}{|c|}{ 2008:10 2010:03 2010:03 2010:03 2008: } & 10 & \multicolumn{3}{|c|}{ 2010:03 2010:03 2010:03 } \\
\hline & 11 & $\underline{2} 1$ & $3 \mathbf{n}$ & & $5 \mathrm{~N}$ & $6 \mathbf{n}$ & 71 & el \\
\hline constant & $\begin{array}{l}0.0191 \\
(0.01)\end{array}$ & $\begin{array}{l}-3.0343 \\
(-1.42)\end{array}$ & $\begin{array}{l}--2.8637 \\
(-1.39)\end{array}$ & $\begin{array}{l}-1.9841 \\
(-1.09)\end{array}$ & $\begin{array}{l}-2.0138 \\
(-1.14)\end{array}$ & $\begin{array}{l}-2.7939 \\
(-1.35)\end{array}$ & $\begin{array}{l}-4.0604^{+} \\
(-1.96)\end{array}$ & $\begin{array}{l}-4.5127^{*} \\
(-2.43)\end{array}$ \\
\hline$\triangle \operatorname{AaaTR} 10_{t-1}$ & $\begin{array}{l}-0.8395^{*} \\
(-2.33)\end{array}$ & $\begin{array}{l}-0.7861 \\
(-1.52)\end{array}$ & $\begin{array}{l}-1.3443^{*} \\
(-2.47)\end{array}$ & $\begin{array}{l}-1.1902^{*} \\
(-2.46)\end{array}$ & $\begin{array}{l}-0.6664^{+} \\
(-1.81)\end{array}$ & $\begin{array}{l}-0.6298 \\
(-1.25)\end{array}$ & $\begin{array}{l}-1.2222^{*} \\
(-2.31)\end{array}$ & $\begin{array}{l}-1.0469^{*} \\
(-2.22)\end{array}$ \\
\hline$\triangle$ AaaTR $10_{t-2}$ & $\begin{array}{l}0.4601 \\
(1.26)\end{array}$ & $\begin{array}{l}0.6977 \\
(1.40)\end{array}$ & $\begin{array}{l}0.4866 \\
(0.89)\end{array}$ & $\begin{array}{l}0.5116 \\
(1.05)\end{array}$ & $\begin{array}{l}0.3652 \\
(0.97)\end{array}$ & $\begin{array}{l}0.7884 \\
(1.61)\end{array}$ & $\begin{array}{l}0.6223 \\
(1.17)\end{array}$ & $\begin{array}{l}0.6332 \\
(1.34)\end{array}$ \\
\hline$\triangle A a a T R 10_{t-3}$ & $\begin{array}{l}-0.7821^{*} \\
(-2.32)\end{array}$ & $\begin{array}{l}-1.2694^{* *} \\
(-2.70)\end{array}$ & $\begin{array}{l}-1.4477^{* *} \\
(-3.90)\end{array}$ & $\begin{array}{l}-1.4934^{* *} \\
(-4.80)\end{array}$ & $\begin{array}{l}-0.5751^{+} \\
(-1.76)\end{array}$ & $\begin{array}{l}-0.9776^{* *} \\
(-3.43)\end{array}$ & $\begin{array}{l}-1.1362^{* *} \\
(-3.12)\end{array}$ & $\begin{array}{l}-1.1881^{* *} \\
(-3.86)\end{array}$ \\
\hline$\left(F P^{*} \triangle A a a T R\right.$ & $(0)_{\mathrm{t}-1}$ & & $\begin{array}{l}1.9064^{+} \\
(1.73)\end{array}$ & $\begin{array}{l}4.4495^{* *} \\
(4.09)\end{array}$ & & & $\begin{array}{l}2.0857^{*} \\
(2.03)\end{array}$ & $\begin{array}{l}4.3792^{* *} \\
(4.22)\end{array}$ \\
\hline$\left(F P^{*} \triangle A a a T R\right.$ & $0)_{\mathrm{t}-2}$ & & $\begin{array}{l}1.1448 \\
(0.99)\end{array}$ & $\begin{array}{l}-0.0011 \\
(-0.00)\end{array}$ & & & $\begin{array}{l}0.8629 \\
(1.16)\end{array}$ & $\begin{array}{l}0.2535 \\
(0.24)\end{array}$ \\
\hline$\left(F P^{*} \triangle A a a T R\right.$ & $0)_{\mathrm{t}-3}$ & & $\begin{array}{l}1.4437 \\
(1.29)\end{array}$ & $\begin{array}{l}0.3146 \\
(0.31)\end{array}$ & & & $\begin{array}{l}0.7386 \\
(0.59)\end{array}$ & $\begin{array}{l}0.2281 \\
(0.23)\end{array}$ \\
\hline $\begin{array}{l}\operatorname{LINVISM}_{\mathrm{t}}(1-4 \\
\operatorname{LISM}_{\mathrm{t}}(5-8)\end{array}$ & $\begin{array}{l}-0.0116 \\
(-0.02)\end{array}$ & $\begin{array}{l}0.7857 \\
(1.39)\end{array}$ & $\begin{array}{l}0.7354 \\
(1.36)\end{array}$ & $\begin{array}{l}0.5079 \\
(1.06)\end{array}$ & $\begin{array}{l}0.5027 \\
(1.12)\end{array}$ & $\begin{array}{l}0.6911 \\
(1.31)\end{array}$ & $\begin{array}{l}1.0106^{+} \\
(1.92)\end{array}$ & $\begin{array}{l}1.1286^{*} \\
(2.39)\end{array}$ \\
\hline $\operatorname{Aug} 9_{\mathrm{t}}$ & $\begin{array}{l}-3.6533^{* *} \\
(-9.29)\end{array}$ & $\begin{array}{l}-3.6515^{* *} \\
(-5.52)\end{array}$ & $\begin{array}{l}-3.5799^{* *} \\
(-5.63)\end{array}$ & $\begin{array}{l}-3.6673^{* *} \\
(-6.51)\end{array}$ & $\begin{array}{l}-3.6068^{* *} \\
(-8.93)\end{array}$ & $\begin{array}{l}-3.5254^{* *} \\
(-5.49)\end{array}$ & $\begin{array}{l}-3.5030^{* *} \\
(-5.67)\end{array}$ & $\begin{array}{l}-3.5884^{* *} \\
(-6.55)\end{array}$ \\
\hline Lehman $_{\mathrm{t}}$ & $\begin{array}{l}-2.5658^{* *} \\
(-6.50)\end{array}$ & $\begin{array}{c}-2.6757^{* *} \\
(-4.03)\end{array}$ & $\begin{array}{l}-2.5115^{* *} \\
(-3.93)\end{array}$ & $\begin{array}{l}-2.5794^{* *} \\
(-4.56)\end{array}$ & $\begin{array}{l}-2.3299^{* *} \\
(-5.65)\end{array}$ & $\begin{array}{l}-2.3198^{* *} \\
(-3.57)\end{array}$ & $\begin{array}{l}-2.2164^{* *} \\
(-3.55)\end{array}$ & $\begin{array}{l}-2.2499^{* *} \\
(-4.06)\end{array}$ \\
\hline
\end{tabular}




\begin{tabular}{|c|c|c|c|c|c|c|c|c|}
\hline$\triangle T E D_{t-1}$ & $\begin{array}{l}-0.4190^{*} \\
(-2.00)\end{array}$ & $\begin{array}{l}-0.1969 \\
(-0.78)\end{array}$ & $\begin{array}{l}-0.1640 \\
(-0.61)\end{array}$ & $\begin{array}{l}-0.4694^{+} \\
(-1.93)\end{array}$ & $\begin{array}{l}-0.3199 \\
(-1.48)\end{array}$ & $\begin{array}{l}-0.1017 \\
(-0.41)\end{array}$ & $\begin{array}{l}-0.0857 \\
(-0.33)\end{array}$ & $\begin{array}{l}-0.3920 \\
(-1.65)\end{array}$ \\
\hline$\Delta T A L F_{t-1}$ & & & & $\begin{array}{l}2.4159^{* *} \\
(5.31)\end{array}$ & & & & $\begin{array}{l}2.3299^{* *} \\
(5.29)\end{array}$ \\
\hline $\begin{array}{l}\text { F-Test all } \\
\text { three lags of } \\
(\triangle A a a T R 10)_{\mathrm{t}-\mathrm{i}}\end{array}$ & $3.25^{*}$ & $3.13^{*}$ & $5.03^{* *}$ & $5.96^{* *}$ & 1.75 & 1.94 & $3.32^{*}$ & $3.67^{*}$ \\
\hline $\begin{array}{l}\text { F-Test all } \\
\text { three lags of } \\
\left(F P^{*} \triangle A a a T R\right)\end{array}$ & 10) $\mathrm{t}_{\mathrm{t}-\mathrm{i}}$ & & $3.61^{*}$ & $8.01^{* *}$ & & & $3.87^{*}$ & $8.64^{* *}$ \\
\hline $\mathrm{R}^{2}$ (corrected) & .593 & .303 & .354 & .493 & .563 & .294 & .349 & .489 \\
\hline S.E. & 0.3860 & 0.6529 & 0.6285 & 0.5567 & 0.3967 & 0.6354 & 0.6102 & 0.5408 \\
\hline $\operatorname{LM}(2)$ & 0.36 & 3.63 & 1.48 & 0.34 & 0.42 & 2.74 & 2.33 & 0.06 \\
\hline $\mathrm{Q}(4)$ & 5.90 & $20.59^{* *}$ & $22.48^{* *}$ & $8.93^{+}$ & 5.70 & $19.83^{* *}$ & $20.98^{* *}$ & $8.64^{+}$ \\
\hline $\mathrm{Q}(12)$ & $20.07^{+}$ & $27.25^{*}$ & $28.65^{* *}$ & 13.65 & $20.74^{+}$ & $28.49^{* *}$ & $27.71^{* *}$ & 15.65 \\
\hline
\end{tabular}

